Historic, archived document

Do not assume content reflects current scientific knowledge, policies, or practices. 

1281.9

Ag 8

C 2

\section{THE INTEGRATION OF SELECTED \\ BOLL WEEVIL SUPPRESSION TECHNIQUES IN AN ERADICATION EXPERIMENT}

PRODUCTION RESEARCH REPORT NO. 152

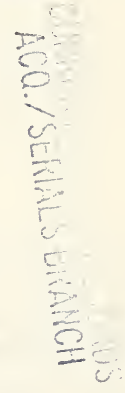

Agricultural Research Service

UNITED STATES DEPARTMENT OF AGRICULTURE In Cooperation With

Texas Agricultural Experiment Station 


\section{ACKNOWLEDGMENTS}

The assistance of the Boll Weevil Research Laboratory, State College, Miss., the Plant Protection Programs of the Animal and Plant Health Inspection Service, U.S. Department of Agriculture, the Cotton Producers Institute, the Plains Cotton Growers, Inc., and the Texas Department of Agriculture in these studies is gratefully acknowledged. Special thanks are due to E. P. Lloyd of the Boll Weevil Research Laboratory for his invaluable assistance in designing the insect-collecting machine.

Also, the Plant Protection staff provided the aircraft and pilot for applying insecticides in the reproductive-diapause control program on the Graves farm in the fall of 1968.

\section{CONTENTS}

Page

Purpose and scope

Supporting experiments _... 3

In-furrow applications of aldicarb

Boll weevil trapping systems _... 3

Mechanical sampling of boll weevils on fruiting cotton ...... 7

Specific eradication experiment

Reproduction-diapause control

Movement of boll weevils to and from Graves farm ...... 9

Pheromone wing traps _.... 10

Soil applications of aldicarb

Sampling of insect populations

Relative value of suppression techniques on the Graves farm and feasibility of eradication plan for belt-wide usage _... 19

Summary _.

Literature cited _.

Washington, D.C.

Issued October 1973

For sale by the Superintendent of Documents, U.S. Government Printing Office,

Washington, D.C. 20402 - Price: 40 cents

Stock Number $0100-02853$ 


\title{
THE INTEGRATION OF SELECTED BOLL WEEVIL SUPPRESSION TECHNIQUES IN AN ERADICATION EXPERIMENT
}

\author{
By J. R. COPPEDG and R. L. RIDGWAY, Southern Region, \\ Agricultural Research Service
}

Knipling (1968) ${ }^{1}$ estimated that the boll weevil (Anthonomus grandis Boheman) causes cotton-production losses ranging from $\$ 200$ to $\$ 300$ million annually and that cotton producers spend up to $\$ 75$ million each year to prevent even higher losses. He also suggested that if broad-spectrum insecticides were no longer necessary for boll weevil control, damaging infestations of the bollworm (Heliothis zea (Boddie)) and the tobacco budworm ( $H$. virescens (F.)) in cotton would be less frequent. In view of the extensive losses caused by the boll weevil and the growing concern over the side effects produced by the insecticides applied each year for its control, it is apparent that it would be profitable to the cotton industry and the Nation as a whole to eradicate this pest (Knipling 1964).

\section{PURPOSE AND SCOPE}

Eradicating the boll weevil has long been the goal of many entomologists. However, only recently has this goal appeared attainable with the introduction of several new boll weevil control methods and the improvement of certain existing procedures. Therefore, the research reported here was undertaken to demonstrate the feasibility of boll weevil eradication. The first step was to review the most promising current suppression methods and to select those that might be the most practical. Since such suppression methods as reproductiondiapause control, coordinated spring applications of insecticides, traps baited with the boll weevil pheromone, trap plots, and release of sterile males appear particularly promising, their status will be reviewed briefly.

The value of late-season application of insecticides to reduce the number of diapausing weevils in the fall and concomitantly the number leaving overwintering quarters in the spring was first demonstrated by Brazzel (1961) and Brazzel et al. (1961). Previous

\footnotetext{
${ }^{1}$ The year in italic after the author's name indicates the reference in Literature Cited, p. 23.
}

studies by Brazzel and Newsom (1959) demonstrated that the boll weevil requires a period of development in the fall before it can successfully overwinter. In related studies Adkisson et al. (1965) obtained approximately 90percent control of the boll weevil with four insecticide applications in the fall at 10- to 14-day intervals.

Knipling ${ }^{2}$ suggested that this level of reduction can mean practical control under some conditions but will only delay the development of economic populations by about one generation in favorable situations. After carefully considering available information on the life history of the boll weevil, Knipling suggested that six to seven insecticide treatments properly scheduled in the fall should produce more than 99-percent suppression of the weevil population. This level of control has been achieved

\footnotetext{
${ }^{2}$ KNIPling, E. F. AN Appraisal OF THE RElative MERITS OF INSECTICIDAL CONTROL DIRECTED AGAINST REPRODUCING VERSUS DIAPAUSING BOLL WEEVILS IN EFFORTS TO DEVELOP ERADICATION PROCEDURES. [Letter dated Jan. 28, 1963, addressed to members of the Cotton Insects Res. Br., Ent. Res. Div., Agr. Res. Serv., U.S. Dept. Agr.]
} 
by several research groups when this proposed schedule was used (Lloyd et al. 1964; Adkisson and Sterling 1965; Fye et al. 1968).

The repeated foliar applications of insecticides in the spring, as originally suggested by Ewing and Parencia (1949), is also an effective boll weevil suppression technique. However, Knipling (1968) indicated that such a program will not assure boll weevil control throughout the season for long-fruiting cotton.

Soil applications of aldicarb are highly effective against the boll weevil (Ridgway and Gorzycki 1965; Hopkins and Taft 1965; Cowan et al. 1966; Ridgway et al. 1968; Coppedge et al. 1969; Bariola et al. 1971). Coppedge et al. (1969) obtained from 2 to 4 weeks' boll weevil control in northwest Texas with a single side-dressing of 2 pounds of aldicarb per acre and up to 5 weeks' control with two applications of 2 pounds of aldicarb per acre made 9 to 10 days apart. Bariola et al. (1971) reported similar results with side-dressings of aldicarb and obtained up to 94-percent control of boll weevils in the same area with an infurrow application of 1 pound of aldicarb per acre. However, the excellent control of overwintered boll weevils with in-furrow applications of aldicarb may be somewhat unique to northwest Texas since most of the cotton is planted relatively late in this area-from midMay to early June-and the maximum emergence of boll weevils from overwintering quarters appears to occur relatively soon after planting (Ridgway et al. 1971).

Knipling and McGuire (1966) proposed that it might be practical to rear and confine male boll weevils to trap female boll weevils as a means of eliminating low populations of this insect. This proposal was made following research which demonstrated that a windborne pheromone emitted by the male weevil attracts female boll weevils (Keller et al. 1964; Cross and Mitchell 1966). Cross et al. (1969) reported that Stikem-coated wing traps baited with male boll weevils would attract and catch other boll weevils of both sexes in the field. In preliminary research Hardee et al. (1970) suggested that the male-baited wing traps may be effective for boll weevil control when used against low populations. However, the efficiency of these traps in decreasing weevil populations has not been clearly defined.

Trap plots of cotton have been suggested as a means of boll weevil control for many years (Mally 1901). Previous studies using these plots for boll weevil suppression were conducted on the assumption that cotton plants produced an attractant for these insects. Although the cotton plant apparently produces an attractant (Keller et al. 1963, 1965; Neff and Vanderzant 1963; Hardee et al. 1966a, $b$, $c$; Daum et al. 196\%), the boll weevil pheromone appears many times more effective in attracting other weevils (Hardee et al. 1969). Hardee et al. (1969) also conjectured that male boll weevils may initially locate cotton by random movement and then attract other migratory boll weevils to the food source with an aggregating pheromone. This information has renewed interest in trap plots as a means of boll weevil control.

A natural system consisting of free-living male boll weevils on cotton plants may provide the most effective system for attracting boll weevils. Consequently, trap plots baited with male boll weevils and treated with insecticides or trap plots baited with sterile male boll weevils may be more effective in suppressing populations than caged weevils in wing traps. $^{3}$

The sterility principle appears to offer the most practical method of eliminating low boll weevil populations (Knipling 1964). However, most sterilization methods reduce the survival period and competitiveness of the males (Davich and Lindquist 1962; Lindquist et al. 1964; Davich et al. 1965). Also, these researchers encountered regeneration of fertility by sterilized boll weevils. Nevertheless Davich et al. $(1965,1967)$ used sterilized male boll weevils, known to be less competitive than normal males, to suppress boll weevil populations. After considering the available data on these boll weevil suppression methods, several supporting experiments were designed to provide additional information on certain suppression methods. Finally, an experiment was

\footnotetext{
${ }^{3}$ Knipling, E. F. Personal communication dated Jan. 31, 1968. Copy on file Agr. Res. Serv., U.S. Dept. Agr., Beltsville, Md.
} 
planned specifically to demonstrate the technical feasibility of boll weevil eradication.

The supporting experiments included studies of (1) in-furrow applications of aldicarb for boll weevil control, (2) boll weevil trapping systems, and (3) mechanical sampling of boll weevils on fruiting cotton. For the specific eradication experiment, the suppression techniques selected were (1) reproductiondiapause control, (2) pheromone wing traps, and (3) in-furrow and side-dress applications of aldicarb.

\section{SUPPORTING EXPERIMENTS}

In-Furrow Applications of Aldicarb

Research conducted during 1968 indicated in-furrow applications of aldicarb were effective against overwintered boll weevils in northwest Texas (Bariola et al. 1971). Similar tests were conducted in 1969 to further evaluate this method of applying aldicarb.

Methods.-The cotton plots on which these evaluations were conducted were planted the last week in May or the first week in June 1969. Lankart 57 variety cottonseed was used. A 10-percent granular formulation of aldicarb was applied at the time of planting with granular applicators attached to available cotton planters. Originally five plots of 5 to 20 acres each were treated with 1 pound of aldicarb per acre on the Sherrod, Penrod, Fitzgerald, Snow, and Sossaman farms and four plots of 5 to 8 acres each were treated with 2 pounds of aldicarb per acre on the Penrod, Fitzgerald, Snow, and Sossaman farms. However, two of the former plots (Fitzgerald and Sossaman farms) and three of the latter plots (Penrod, Fitzgerald, and Sossaman farms) were destroyed by hail and inclement weather approximately $31 / 2$ weeks after planting. One plot on the Fitzgerald farm was replanted and re-treated with 1 pound of aldicarb per acre the last week in June.

Until July 15 approximately 2,000 row feet of cotton were manually sampled weekly in each plot. From July 15 to September 1, 150 to 400 row feet of cotton per plot were sampled weekly. At each inspection the numbers of boll weevils, fruiting forms containing boll weevil oviposition punctures, Heliothis larvae, fruiting forms damaged by Heliothis, and total fruiting forms were recorded. Also, during the first 3 to 4 weeks after planting, plant stand counts were made at each inspection.
At approximately 1-week intervals starting July 15 , the experimental plots were sampled with an insect-collecting machine.

Results.-Plant stand reductions were noted in all experimental plots receiving in-furrow applications of aldicarb. These reductions were most evident in those plots treated with 2 pounds of aldicarb per acre. These plots had on an average 31 percent fewer plants than the untreated plots (table 1 ).

The results from manual sampling of the experimental plots indicated that excellent control of overwintered boll weevils was obtained with the in-furrow applications of aldicarb (table 1). No adult boll weevils or boll weevil-damaged squares were found in the treated plots from the time of cotton emergence until July 20 as compared with an average of 9.5 adult boll weevils and 20.4 punctured squares per acre detected in the untreated plots during this period.

Boll weevil populations were low at all locations from July 15 to August 20. Because of these low-level populations, meaningful data were obtained on the Sherrod farm only. Manual and mechanical sampling of boll weevils on this farm until August 20 indicated from 91- and 84-percent control, respectively, with 1 pound of aldicarb per acre (table 1 ).

More Heliothis larvae and more squares and bolls damaged by Heliothis larvae were found in treated than untreated cotton (table 2). However chemical control was not required on any of the experimental plots.

\section{Boll Weevil Trapping Systems}

Trap plots of cotton baited with live male boll weevils apparently have the potential of providing a highly efficient system for attracting boll weevils. Theoretically such a system 
should be useful in eliminating low-level boll weevil populations. Therefore a study was conducted in which cotton plants only, cotton plants treated with aldicarb, cotton plants treated with aldicarb plus male-baited wing traps, and male-baited wing traps were compared for effectiveness in attracting boll weevils. Also, an experiment was conducted to investigate the competitiveness of male-baited fruiting cotton plants as compared to male-baited wing traps.

Methods.-In the first trapping experiment, cotton plants in the two to three true leaf stage were used initially in all plots. They were grown in the greenhouse at College Station, Tex., in BR-8 Synthetic Soil Blocks or 8ounce paper cups. Approximately $31 / 2$ weeks after planting, they were removed from the greenhouse and placed outdoors for 2 weeks. Then they were transferred to northwest Texas for transplanting. Seed from an early fruiting experimental variety of cotton supplied by $\mathrm{L}$. S. Bird, Plant Sciences Department, Texas A\&M University, College Station, was used for the original transplants.

The young cotton plants were transplanted into the experimental plots on April 24-30, 1969. One hundred cotton plants were placed in each of two 50-foot trenches approximately
8 inches deep, 3 inches wide, and 40 inches apart. The trenches were prepared at the edge of cultivated land with a roto-tiller and various handtools. In plots treated with aldicarb, an equivalent of 4 pounds of aldicarb per acre was added to the trenches just prior to adding the plants.

After the plants were transferred to the prepared trenches, they were carefully surrounded with soil and watered thoroughly. When small animals began to damage the cotton in some of the experimental plots, the two rows of cotton in the damaged plots were each enclosed with 1/2-inch mesh hardware cloth.

Even though precautionary measures were taken, some of the plants were severely damaged by inclement weather, small animals, and insects, and they had to be replaced. When a single cotton plot had to be replaced, the cotton in all plots at that location was replaced so that all replicates there contained the same age cotton plants.

Fruiting cotton plants were used for the later plantings. They were of the Deltapine Smoothleaf variety and were grown for about 60 days in 1-gallon containers (two plants per container) in the greenhouse at College Station. To transplant them, the metal containers

TABLE 1.-Adult boll weevils and oviposition-punctured squares in experimental plots treated with in-furrow application of aldicarb, 1969

\begin{tabular}{|c|c|c|c|c|c|}
\hline \multirow{2}{*}{$\begin{array}{l}\text { Sampling method } \\
\text { and } \\
\text { treatment }\end{array}$} & \multirow[b]{2}{*}{$\begin{array}{l}\text { Stand } \\
\text { reduction }\end{array}$} & \multirow[b]{2}{*}{$\begin{array}{l}\text { Adult boll } \\
\text { weevils }\end{array}$} & \multirow[b]{2}{*}{$\begin{array}{l}\text { Punctured } \\
\text { squares }\end{array}$} & \multicolumn{2}{|c|}{ Reduction of- } \\
\hline & & & & $\begin{array}{l}\text { Adult boll } \\
\text { weevils }\end{array}$ & $\begin{array}{l}\text { Punctured } \\
\text { squares }\end{array}$ \\
\hline & Percent & Number per acre & umber per acre & Percent & Percent \\
\hline & & OVERWINTERED WEI & LS TO JULY $20, \mathrm{AV}$ & ERAGE $1-3$ FARMS ${ }^{1}$ & \\
\hline \multicolumn{6}{|c|}{ 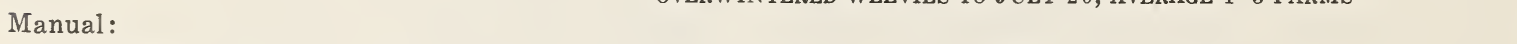 } \\
\hline Untreated $\ldots \ldots$ & .... & 9.5 & 20.4 & .... & .... \\
\hline 1 pound per acre & 5 & 0 & 0 & 100 & 100 \\
\hline \multirow{2}{*}{2 pounds per acre $\ldots . . . .}$. & 31 & 0 & 0 & 100 & 100 \\
\hline & \multicolumn{5}{|c|}{ F. WEEVILS TO AUG. 20 , SHERROD FARM ONLY } \\
\hline \multicolumn{6}{|l|}{ Manual: } \\
\hline Untreated & $\ldots$ & 93.7 & 2,244 & ... & -.. \\
\hline 1 pound per acre & $\ldots$ & 8.7 & 381 & 91 & 83 \\
\hline \multicolumn{6}{|l|}{ Mechanical: } \\
\hline Untreated & $\ldots$ & 37.8 & 262 & & $\ldots$ \\
\hline 1 pound per acre & -.. - & 6.0 & 25 & 84 & 90 \\
\hline
\end{tabular}

${ }^{1}$ Stand counts are average of records from 3 plots for each treatment. Boll weevils and boll weevil-punctured square counts are an average of records from 3 plots for 1-pound-per-acre treatment and untreated check, but are the total of records from a single plot treated with 2 pounds of aldicarb per acre. 
THE INTEGRATION OF SELECTED BOLL WEEVIL

TABLE 2.-Heliothis larvae and squares and bolls damaged by Heliothis larvae per acre on farms treated with in-furrow applications of aldicarb, 1969

\begin{tabular}{|c|c|c|c|c|c|c|c|}
\hline \multirow[b]{2}{*}{ Date } & & \multicolumn{3}{|c|}{ Heliothis larvae ${ }^{1}$} & \multicolumn{3}{|c|}{ Damaged squares and bolls } \\
\hline & & Untreated & $\begin{array}{l}1 \text { pound per } \\
\text { acre }\end{array}$ & $\begin{array}{l}2 \text { pounds per } \\
\text { acre }\end{array}$ & Untreated & $\begin{array}{l}1 \text { pound per } \\
\text { acre }\end{array}$ & $\begin{array}{c}2 \text { pounds per } \\
\text { acre }\end{array}$ \\
\hline July 14 & & $\begin{array}{c}\text { Number } \\
31\end{array}$ & $\begin{array}{c}\text { Number } \\
477\end{array}$ & $\underset{65}{\text { Number }}$ & $\underset{65}{N u m b e r}$ & $\begin{array}{l}\text { Number } \\
2,041\end{array}$ & $\begin{array}{c}\text { Number } \\
260\end{array}$ \\
\hline 17 & - & 31 & 271 & 0 & 77 & 2,568 & 186 \\
\hline 21 & - & 0 & 43 & 0 & 22 & 968 & 43 \\
\hline 24 & - & 0 & 21 & 0 & 0 & 183 & 0 \\
\hline 29 & & 0 & 188 & 72 & 62 & 606 & 260 \\
\hline Aug. 4 & - n-n & 411 & 1,433 & 650 & 1,184 & 3,393 & 1,560 \\
\hline 11 & - & 529 & ... & $\ldots$ & 1,212 & & _. - \\
\hline 15 & - & 143 & 310 & $\ldots$ & 765 & 3,068 & _. - \\
\hline 20 & - & 17 & 221 & 102 & 527 & 1,851 & 1,025 \\
\hline
\end{tabular}

${ }^{1}$ Found while searching $1 / 3$-grown squares or larger for boll weevils.

were carefully removed and the plants and potting soil transferred to prepared holes approximately 8 inches deep, 6 inches wide, and 1 foot apart. One row of plants, 10 feet long and containing 20 plants (two plants per hole), constituted a plot. When the plots were to be treated with aldicarb, an equivalent of 4 pounds of aldicarb per acre was added to the prepared holes immediately before the plants.

The wing traps used in this study were constructed of lightweight sheet metal and were painted yellow. Each trap consisted of two wings, $113 / 4$ by 10 inches, at a $45^{\circ}$ angle with each other and held together with a 12 - by 12 inch base and a $6^{\prime}$ by 6 -inch top plate. The wing traps were coated with Stikem and placed on 5-foot wooden poles, $1 \frac{1}{2}$ inches in diameter, which had been driven approximately $11 / 2$ feet into the soil. When the wing traps were placed at the locations where the cotton was transplanted in the two to three leaf stage, two wing traps 50 feet apart were used. When the traps were used at the same location where the plots contained cotton transplanted in the fruiting stage, the two wing traps were placed 10 feet apart.

Each wing trap contained four male boll weevils each in a separate compartment of a $21 / 2$ - by 6 -inch screen cylinder closed with a metal lid and partitioned with water-resistant cardboard. The boll weevils used in this study were laboratory reared and sexed at the Boll
Weevil Research Laboratory, Starkville, Miss. They were shipped by air from Memphis, Tenn., to Lubbock, Tex., from where they were transferred by automobile to Crosbyton, Tex. At the Crosbyton laboratory they were placed in screen cages.

To sustain the weevils, two live cotton cotyledons and adult diet pellets (Gast and Davich 1966) were added to each compartment of the cage. To keep the cotyledons alive as long as possible, the lower half of each plant was placed in a water-filled vial ("aquapicks" or "orchid tubes"), which was one-half inch in diameter and $21 / 2$ inches long. To hold the plants in an upright position and to prevent excessive spillage and evaporation of the water, the vials were equipped with slit and notched rubber caps that fitted securely around the cotyledons. The prepared cages of boll weevils were transferred from the Crosbyton laboratory twice each week, normally Tuesday and Friday, during the summer by automobile to Guthrie, Tex., where they were held at $23^{\circ}$ $27^{\circ} \mathrm{C}$. until used.

One replicate of each trapping system was located at each of five locations. Each of the four treatments was placed approximately the same distance apart and on the same side of a field. Prior to the first inspection of the plots, the area underneath the plants was covered with unbleached domestic muslin to aid in recovering dead weevils. 
Starting on June 13, 1969, all four trapping systems were inspected at 2- to 3-day intervals. The cotton plants were searched for live boll weevils, the cloth underneath the plants for dead weevils, and the wing traps for captured weevils. Fresh cages of weevils were added to the wing traps at each inspection. All live and dead native boll weevils were removed from the plots at each inspection.

In the second trapping experiment, malebaited cotton plants were compared to malebaited wing traps for effectiveness in capturing boll weevils. Fifteen 4 -foot plots of heavily fruiting cotton (eight plants per plot), transplanted as previously described, were positioned approximately an equal distance apart around the cultivated part of a cotton farm (Graves farm, King County, Tex.). All plots were placed on the edge of cultivated land and centered between two wing traps, which were 200 feet apart. These wing traps were part of a series of 111 wing traps 200 feet apart that had been previously installed for boll weevil suppression. Each wing trap contained four male boll weevils fed cotton cotyledons and adult diet pellets. Two days prior to the first inspection of the plots, four laboratoryreared male boll weevils marked with a fastdrying paint (Testors Butyrate Dope, Testors Corp., Rockfort, Ill.) were released in each of the cotton plots. The cotton plots and wing traps were inspected three times during a 10day period.

Results.-In the first trapping experiment, the cotton plants treated with aldicarb plus wing traps attracted or destroyed significantly more boll weevils than the other trapping systems (table 3). The wing traps in the plots with aldicarb-treated cotton captured about the same number of boll weevils as the wing traps alone; however, from four to six times as many boll weevils were caught on the cotton in plots with wing traps than on the cotton in plots without wing traps. These data clearly show the value of a source of boll weevil pheromone in trap plots and also indicate that male-baited wing traps may attract considerably more boll weevils than they actually catch.

A comparable number of live boll weevils was found on cotton plants alone and cotton plants plus aldicarb. Apparently, the adult boll weevils that entered the aldicarb-treated plots were not immediately destroyed and lived long enough to produce some pheromone. Probably the amount of time necessary for the boll weevils to locate, infest, and be destroyed by the aldicarb-treated cotton was greater than the 48 to 72 hours between inspections. The insecticide activity of the treated plants was

TABLE 3.-Comparative effectiveness of different trapping systems for attracting or destroying overwintered boll weevils, 1969

\begin{tabular}{|c|c|c|c|c|c|}
\hline \multirow{2}{*}{$\begin{array}{l}\text { Experiment } \\
\text { and } \\
\text { kind of trap }\end{array}$} & \multicolumn{4}{|c|}{ Average catch of boll weevils per trap per inspection } & \multirow{2}{*}{$\begin{array}{l}\text { Actual } \\
\text { catch of } \\
\text { weevils }\end{array}$} \\
\hline & $\begin{array}{l}\text { On plants } \\
\text { (alive) }\end{array}$ & $\begin{array}{l}\text { On ground } \\
\text { (dead) }\end{array}$ & $\begin{array}{l}\text { On wing trap } \\
\text { (dead) }\end{array}$ & Total $^{1}$ & \\
\hline Experiment 1 & Number & Number & Number & Number & Number \\
\hline Cotton plants only & 0.38 & 0 & ... & $0.38 \mathrm{a}$ & 25 \\
\hline Cotton plants + aldicarb . . . . . . & .61 & .07 & $\ldots$ & $.68 \mathrm{a}$ & 46 \\
\hline $\begin{array}{l}\text { Cotton plants }+ \text { aldicarb }+ \text { male- } \\
\text { baited wing traps }\end{array}$ & 2,21 & 46 & & & \\
\hline $\begin{array}{c}\text { Male-baited wing traps } \\
\text { Experiment } 2\end{array}$ & 2.21 & .46 & $\begin{array}{l}3.61 \\
3.66\end{array}$ & $\begin{array}{l}6.28 \mathrm{~b} \\
3.66 \mathrm{c}\end{array}$ & $\begin{array}{l}421 \\
245\end{array}$ \\
\hline $\begin{array}{l}\text { Male-baited cotton plants } \\
\text { Male-baited wing traps: }\end{array}$ & 3.20 & $\ldots$ & -. - & $3.20 \mathrm{a}$ & 96 \\
\hline 100 feet from plants & ... & $\ldots$ & .72 & $.72 \mathrm{~b}$ & 43 \\
\hline $500-700$ feet from plants ... & ... & ... & .42 & $.42 \mathrm{~b}$ & 25 \\
\hline
\end{tabular}

${ }^{1}$ Means not followed by common letter are significantly different at 5-percent level (Duncan's Multiple Range Test). 
confirmed on two occasions during this study. Laboratory-reared boll weevils were caged on excised leaves from the treated plants on June 17 and 28, and on both occasions 100-percent mortality of the caged weevils occurred within 72 hours.

In the second trapping experiment, significantly more boll weevils were captured on the male-baited cotton plants than on the wing traps (table 3 ). The male-baited cotton plants captured approximately four times more boll weevils than the wing traps 100 feet away and eight times more weevils than the wing traps 500 to 700 feet away. Also, the wing traps at 100 feet captured almost twice as many boll weevils as the traps at 500 to 700 feet, possibly indicating that the male-baited cotton plants may have affected weevil catches on the nearest wing traps. Apparently, a trapping system utilizing caged male boll weevils in traps is considerably less attractive than one consisting of free-living male boll weevils on cotton plants.

\section{Mechanical Sampling of Boll Weevils on Fruiting Cotton}

Meaningful estimates concerning the effectiveness of trying to eradicate the boll weevil require extensive sampling of treated cotton. To accomplish the necessary amount of sampling by manual means would be both time consuming and costly. A more rapid and less expensive method of sampling large amounts of cotton may be with an insect sampling machine (Kirk and Bottrell 1969). The following study was conducted to determine the efficiency of an insect sampling machine in detecting boll weevil populations on fruiting cotton.

Methods.-Manual and mechanical sampling were compared for effectiveness in detecting adult boll weevils and boll weevil-punctured squares on four occasions from August 12 to September 4, 1969. Mechanical sampling of boll weevils on cotton was accomplished with a two-row insect-collecting machine (fig. 1). This machine was mounted in front of a tractor. An airstream of approximately 100 m.p.h. was generated with paddle fans at-
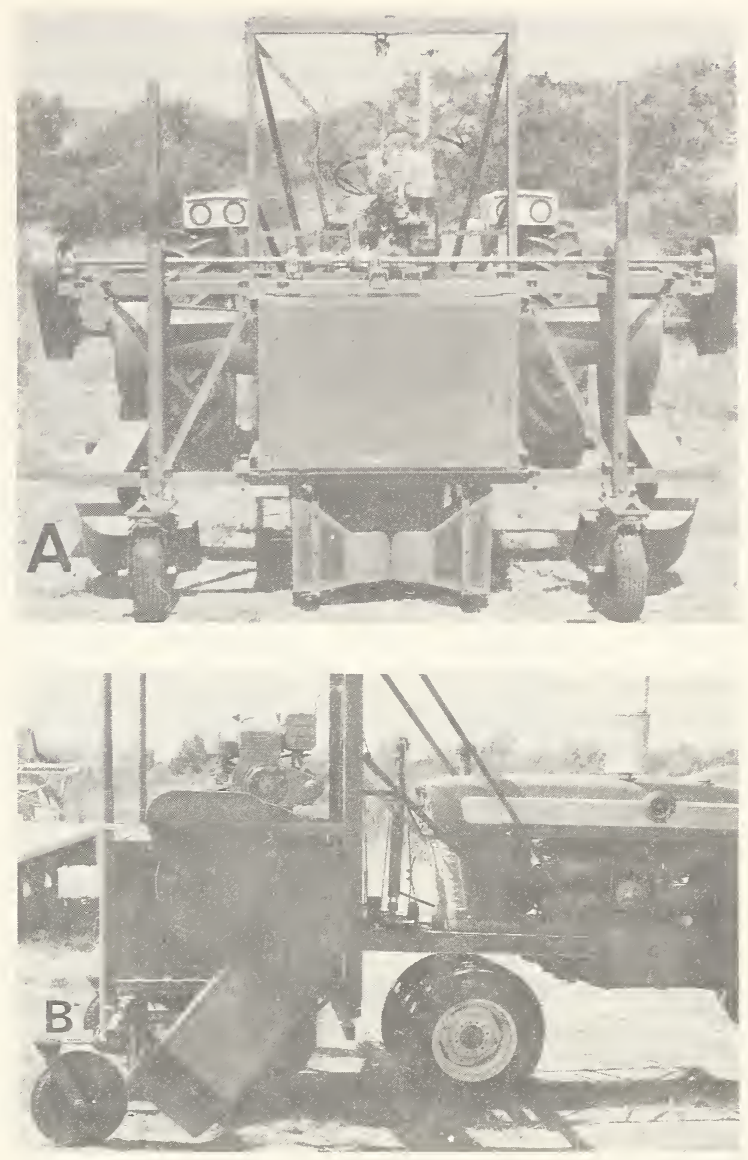

$\mathrm{PN}-3334 / \mathrm{PN}-3335$

FIgURE 1.-Tractor-mounted insect-collecting machine: $A$, Front view; $B$, side view.

tached to a 12-hp. gasoline engine. The sampled cotton plants were exposed to both an airblast and suction, as the air blown across the plants was drawn through the same port through which the material blown from the cotton plants entered the machine. The machine was commonly operated at a ground speed of 1.6 m.p.h.

Results.-The average height of the cotton, the amount of cotton sampled, and the results of this experiment are presented in table 4 . Compared with manual sampling of fruiting cotton, the machine appeared to be 38.5-percent efficient in detecting adult boll weevils and 6.8-percent efficient in detecting punctured squares. The efficiency estimate on punctured 
squares was possibly low since in the first test $\mathrm{F}_{1}$ weevils were just beginning to emerge and almost all damaged squares were freshly punctured.

During this study a field crew of six people could sample approximately 2,000 row feet of fruiting cotton per day, whereas a machine crew of three people with a sampling machine could sample approximately 5 acres $(65,000$ row feet) in the same amount of time. Using this information along with the data obtained on the efficiency of the sampling machine, it is possible to calculate that a machine crew could detect a boll weevil infestation of one adult per 10 acres approximately 10 times quicker than the field crew. Undoubtedly the cost of sampling a low boll weevil population would be considerably less by mechanical than by manual means.

\section{TABLE 4.-Comparison of manual and mechanical methods of sampling boll weevil populations, 1969}

\begin{tabular}{|c|c|c|c|c|c|c|c|c|}
\hline \multirow{2}{*}{\multicolumn{2}{|c|}{$\begin{array}{l}\text { Test, } \\
\text { date, } \\
\text { and } \\
\text { sampling } \\
\text { method }\end{array}$}} & \multirow[b]{2}{*}{$\begin{array}{l}\text { Average } \\
\text { height of } \\
\text { cotton }\end{array}$} & \multirow[b]{2}{*}{$\begin{array}{l}\text { Amount of } \\
\text { cotton } \\
\text { sampled }\end{array}$} & \multirow[b]{2}{*}{$\begin{array}{c}\text { Boll } \\
\text { weevils } \\
\text { per acre }\end{array}$} & \multirow[b]{2}{*}{$\begin{array}{l}\text { Boll weevil } \\
\text { oviposition- } \\
\text { punctured } \\
\text { squares per } \\
\text { acre }\end{array}$} & \multirow[b]{2}{*}{$\begin{array}{l}\text { Total } \\
\text { fruiting } \\
\text { forms per } \\
\text { acre }\end{array}$} & \multicolumn{2}{|c|}{$\begin{array}{c}\text { Efficiency of } \\
\text { mechanical sampling }\end{array}$} \\
\hline & & & & & & & Adults & $\begin{array}{c}\text { Ovi- } \\
\text { position } \\
\text { punctured } \\
\text { squares }\end{array}$ \\
\hline & $\begin{array}{l}\text { Test 1 } \\
\text { (Aug. 12) }\end{array}$ & Inches & Row feet & Number & Number & Number & Percent & Percent \\
\hline Manual ... & - & & 300 & 520 & 22,919 & & & \\
\hline Mechanical & $\begin{array}{c}\text { Test } 2 \\
\text { (Aug. 15) }\end{array}$ & 11.1 & 3,630 & 191 & 652 & 114,312 & 36.7 & 2.8 \\
\hline $\begin{array}{l}\text { Manual } \\
\text { Mechanical }\end{array}$ & (1) & 13.7 & $\begin{array}{r}500 \\
4,800\end{array}$ & $\begin{array}{r}182 \\
68\end{array}$ & $\begin{array}{r}6,266 \\
554\end{array}$ & 137,956 & 37.3 & $\overline{8 .-}$ \\
\hline & $\begin{array}{c}\text { Test } 3 \\
\text { (Aug. 21) }\end{array}$ & & & & & & & \\
\hline Manual _.. & - & 159 & 500 & 104 & 4,316 & 132938 & - - & \\
\hline Mechanical & $\begin{array}{c}\text { Test } 4 \\
\text { (Sept. 4) }\end{array}$ & 15.9 & 4,400 & 33 & 232 & 132,938 & 31.7 & 5.4 \\
\hline $\begin{array}{l}\text { Manual } \\
\text { Mechanical }\end{array}$ & (1) & 13.2 & $\begin{array}{r}260 \\
6,272\end{array}$ & $\begin{array}{l}2,900 \\
1,400\end{array}$ & $\begin{array}{r}3,180 \\
328\end{array}$ & 58,500 & 48.2 & 10.2 \\
\hline Aver & $\begin{array}{l}\text { rage: } \\
\text { Manual } \\
\text { Mechanical }\end{array}$ & 13.5 & $\begin{array}{r}390 \\
4,776\end{array}$ & $\begin{array}{l}926 \\
423\end{array}$ & $\begin{array}{r}9,170 \\
442\end{array}$ & 110,927 & 38.5 & 6.8 \\
\hline
\end{tabular}

\section{SPECIFIC ERADICATION EXPERIMENT}

The semi-isolated Graves farm near Guthrie in northwest Texas was selected as the site for the eradication experiment. Previously, Ridgway et al. (1971) indicated that the farm supported a well-established boll weevil infestation and was isolated from adjoining cotton by 13 to 15 miles of rangeland. They found that boll weevils moved across the 13 to 15 miles of rangeland in the spring and again in the fall; however the Graves farm appeared to be somewhat isolated from immigrating boll weevils from late June to mid-August.

After selecting the Graves farm for this experiment, the boll weevil suppression measures were implemented-the reproductiondiapause fall spray program, pheromone wing traps, and soil applications of aldicarb. 


\section{Reproduction-Diapause Control}

Methods and Results.-A reproductiondiapause boll weevil control program was undertaken on the Graves farm in September 1968. The cotton on this farm was treated with malathion applied ultra low volume (ULV) on September 9 and 14 at the rate of 12 fluid ounces per acre and on September 23 and 27, October 11 and 26 at 16 fluid ounces per acre. All applications were made with a Pawnee 235 aircraft equipped with Teejet No. 80015 spray nozzles. The aircraft was flown 25 to 30 feet above the ground while making the applications, and normal swath width was 100 feet.

The boll weevil population on the Graves farm was sampled at 1- to 2-week intervals from September 1 to November 12, 1968. These data (fig. 2) indicated that the level of boll weevil suppression was less than originally anticipated. These results were probably due to the improper timing of insecticide applica- tions, which resulted when inclement weather delayed treatments.

\section{Movement of Boll Weevils to and From Graves Farm}

Methods and Results.-To study boll weevil movement to and from the experimental area, pheromone wing traps were positioned between the Graves farm and adjoining cotton-growing areas. These traps were placed every 0.65 air mile along existing roads to the north, southeast, and southwest of the farm (fig. 3). The arrangement of the traps between the farm and the adjoining cotton-growing areas was similar to that used by Ridgway et al. (1971); however the number of traps per line was increased considerably for this study. These traps were installed $31 / 2$ feet above soil level on wooden poles. They were first baited with live male boll weevils on April 7, 1969, and inspected for the first time on April 10, 1969. At weekly intervals thereafter they were in-

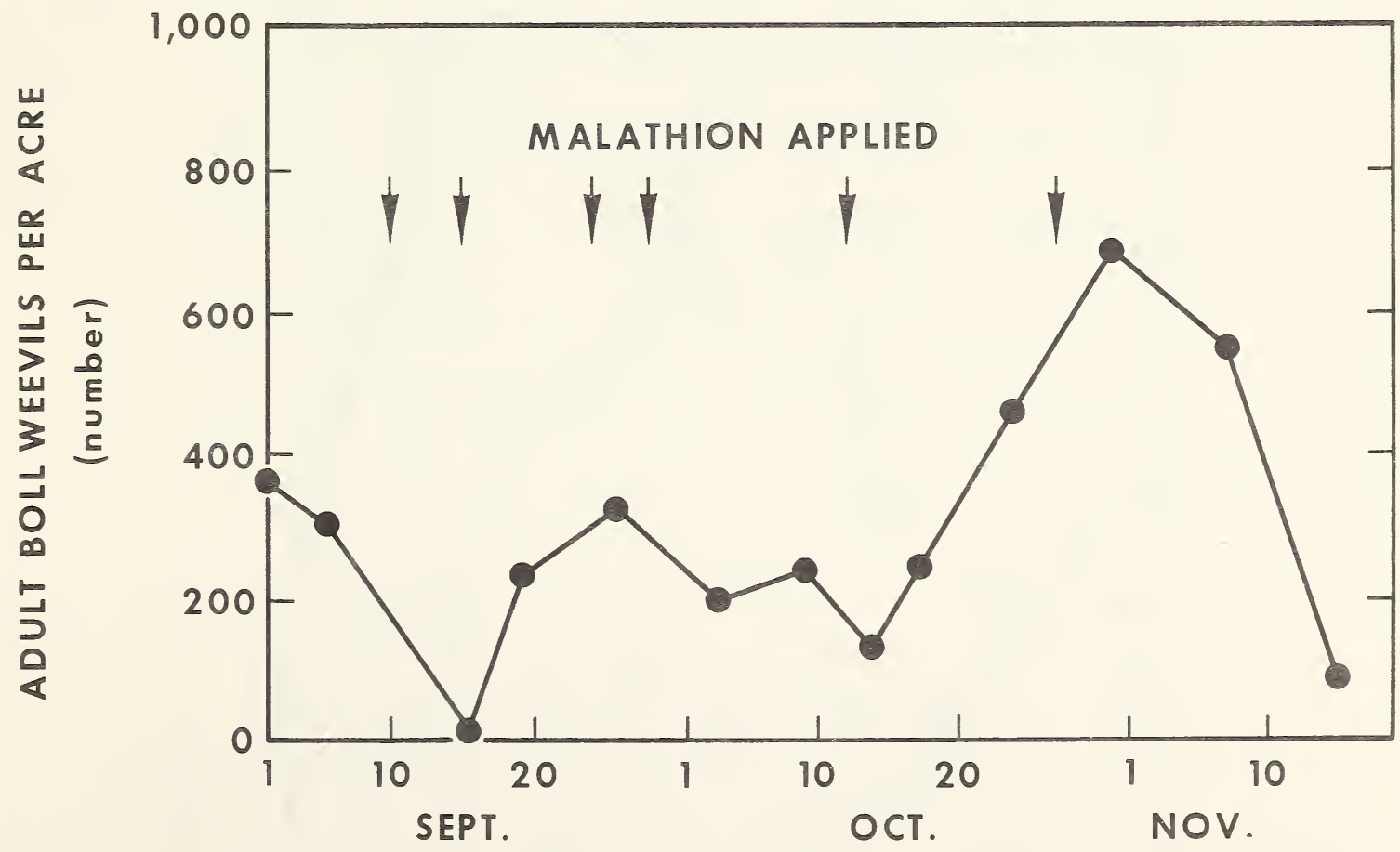

FIGURE 2.-Boll weevil population on Graves farm during reproduction-diapause control period, 1968. 
spected for captured weevils, new weevils and weevil food were added, and when necessary the traps were recoated with fresh adhesive.

Catches on these wing traps indicated considerable movement of boll weevils across the 13 to 15 miles of rangeland during the spring and again in the fall. However, the Graves farm appeared to be fairly well isolated from outside boll weevils from about late June to late August (fig. 4 and table 5). The greatest num- ber of weevils was caught on the southeast line of traps and the smallest number on the north line. These data indicate that most of the boll weevils moving onto the Graves farm probably came from the south.

\section{Pheromone Wing Traps}

Methods and Results.-Wing traps containing caged male boll weevils were placed around

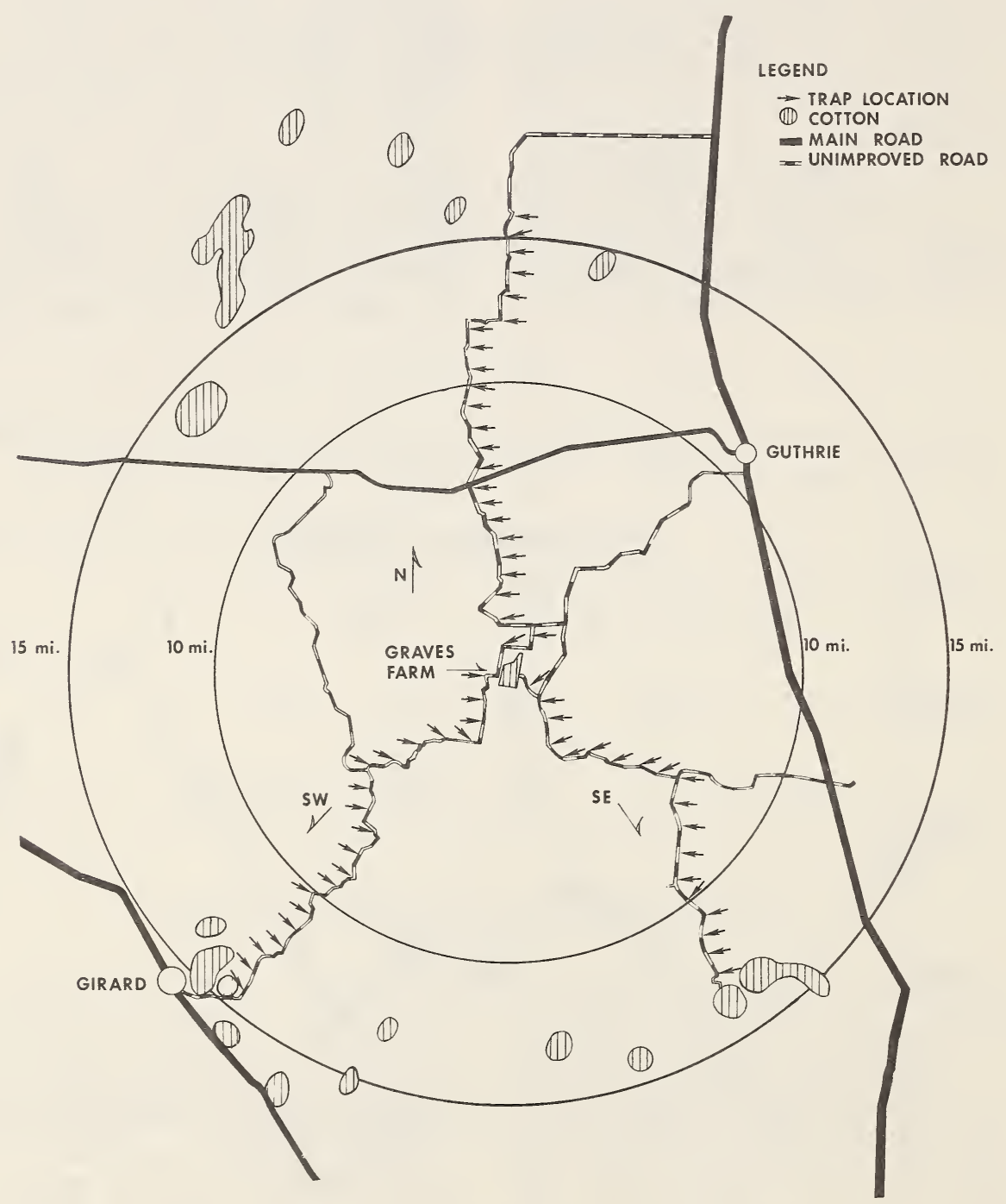

FIGURE 3.-Location of wing traps positioned to study seasonal movement of boll weevils between Graves farm and nearest cotton, 1969. 


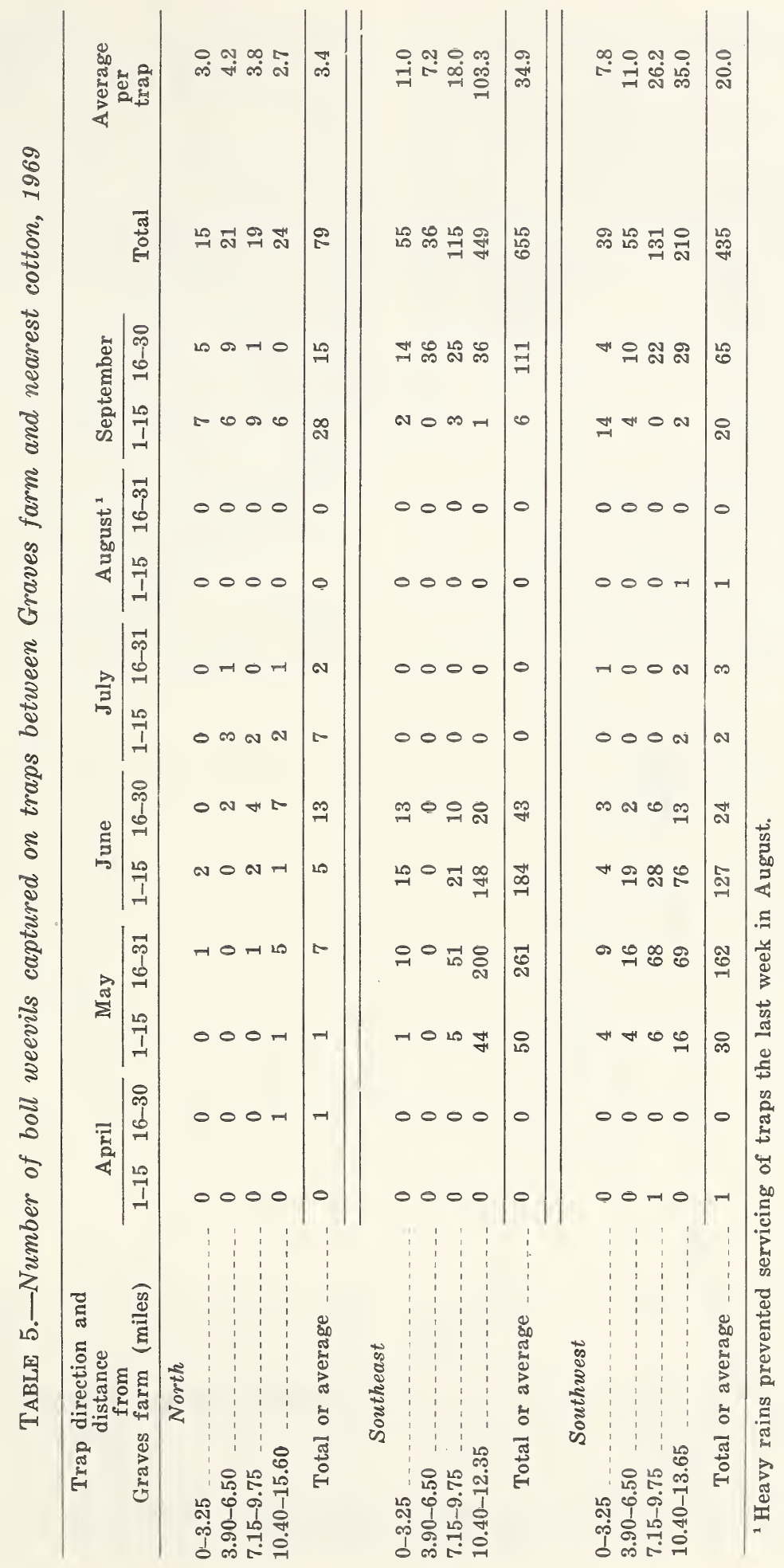


and within the Graves farm to suppress the boll weevils. The first line of wing traps (Aline) was placed on the edge of cultivated land where cotton was to be planted. This line contained 111 wing traps spaced 200 feet apart. The wing traps in the second line (Bline) were placed 250 feet out from and in between the traps in A-line. The B-line contained 110 wing traps. The traps in the A- and $\mathrm{B}$-lines around the fields were subdivided according to location and direction, such as $\mathrm{N}-\mathrm{N}$, which indicated the north field and the north line (fig. 5). In addition to those traps positioned around the farm, wing traps were placed 200 feet apart between the cultivated fields where cotton was to be planted (I-line). About the time cotton started to square, wing traps were placed within the fields of cotton at the rate of one trap per 1.16 acres of planted cotton (I-grid). All traps were installed as previously described and were serviced twice weekly when possible.
During the summer, samples of up to 50 boll weevils captured on the wing traps positioned around the Graves farm were examined and sexed. Also, the percent survival of the caged male boll weevils was recorded.

Boll weevils were first detected on the wing traps located around the Graves farm during the last week in April 1969 (table 6). The peak boll weevil catches on these wing traps occurred the last week in May and the first week in June (fig. 6). After the first week in June, catches declined rapidly and only scattered boll weevils were caught from mid-July until late August. Wing trap catches indicated a second period of extensive boll weevil movement starting the last week in August. Up until this second period of extensive boll weevil movement, approximately 9.5 boll weevils per acre had been removed from the Graves farm with wing traps (table 6).

More boll weevils per trap were captured on the outside line of wing traps (B-line)

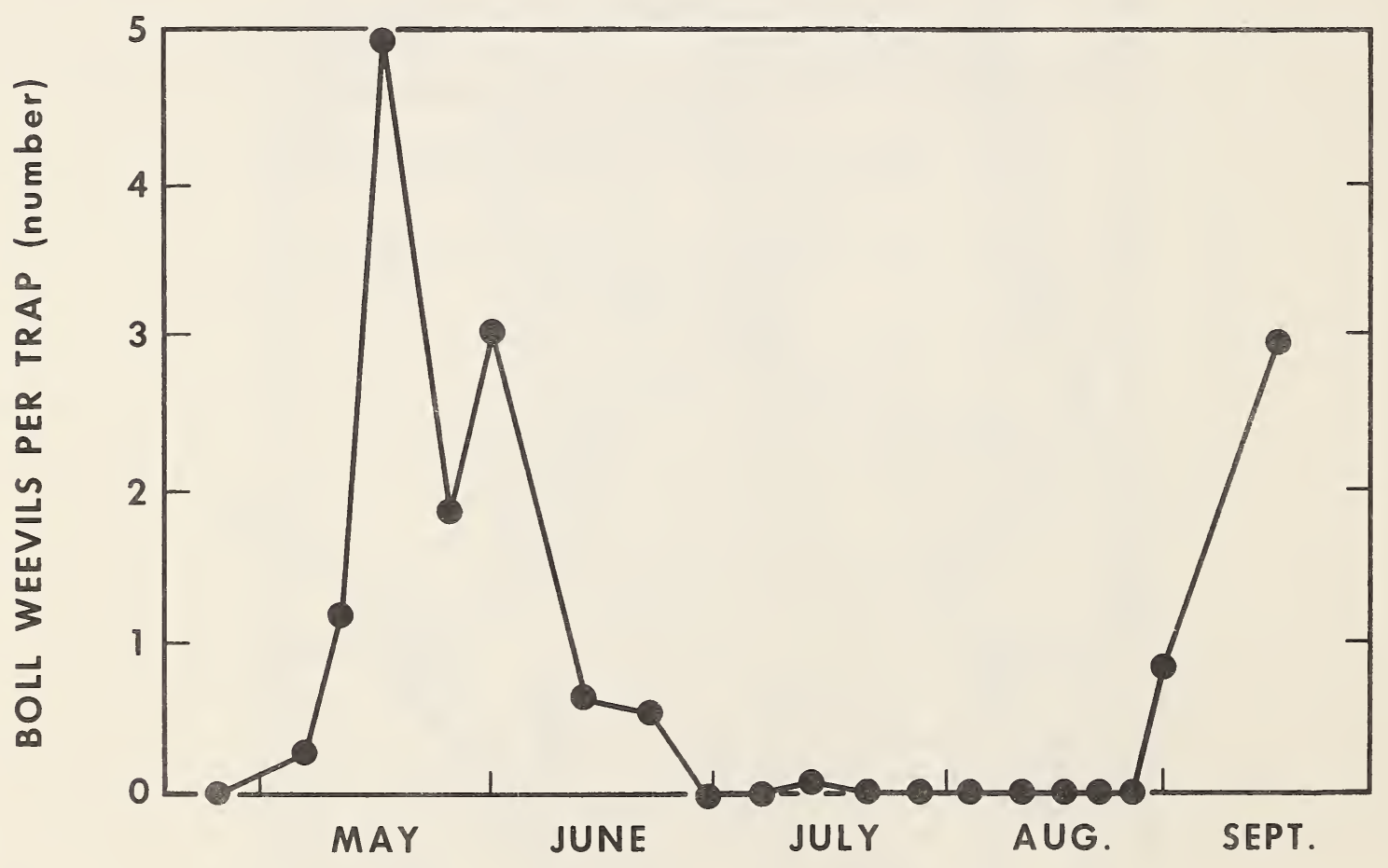

FIGURE 4.-Boll weevils captured on wing traps positioned to study their seasonal movement between Graves farm and nearest cotton, 1969. 


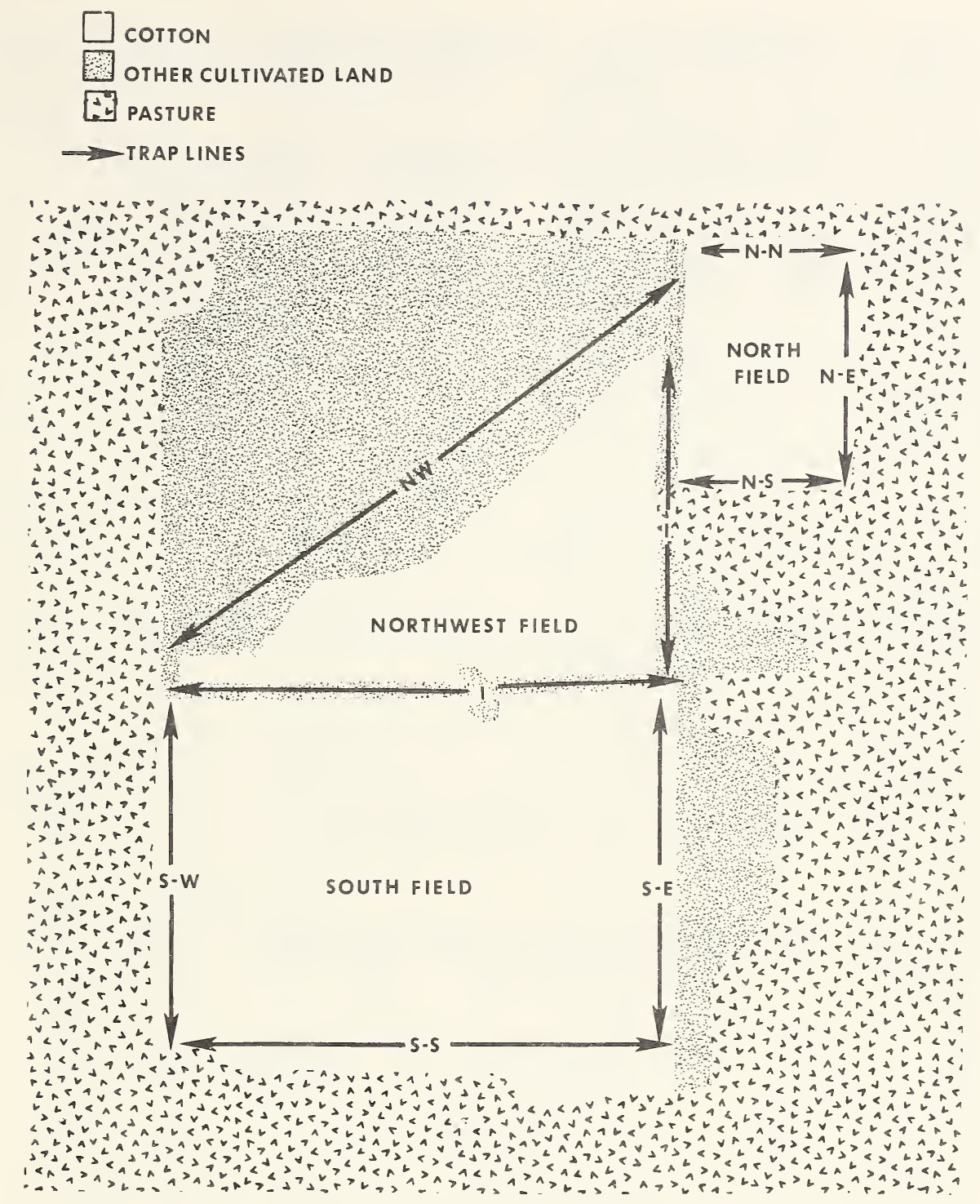

FIGURE 5.-Diagram of Graves farm and location of lines of wing traps, 1969.

than on the inner lines (A-line or I-line). Only four were captured on the wing traps located within the cotton (I-grid). The wing traps installed on the south side of the Graves farm ( S-W, S-S, and S-E, parts of the A- and Blines) captured substantially more boll weevils than the remaining traps. These data suggest again that most of the boll weevils that would have normally infested the cotton on the
Graves farm probably overwintered south of this farm.

More female than male boll weevils were captured on the wing traps, especially after July 15, 1969 (table 7). The survival of the caged male boll weevils, replaced weekly from April 1 to 30 and twice weekly thereafter, was 60 percent or more from May 1 to June 15. After mid-June their survival dropped sharply, 


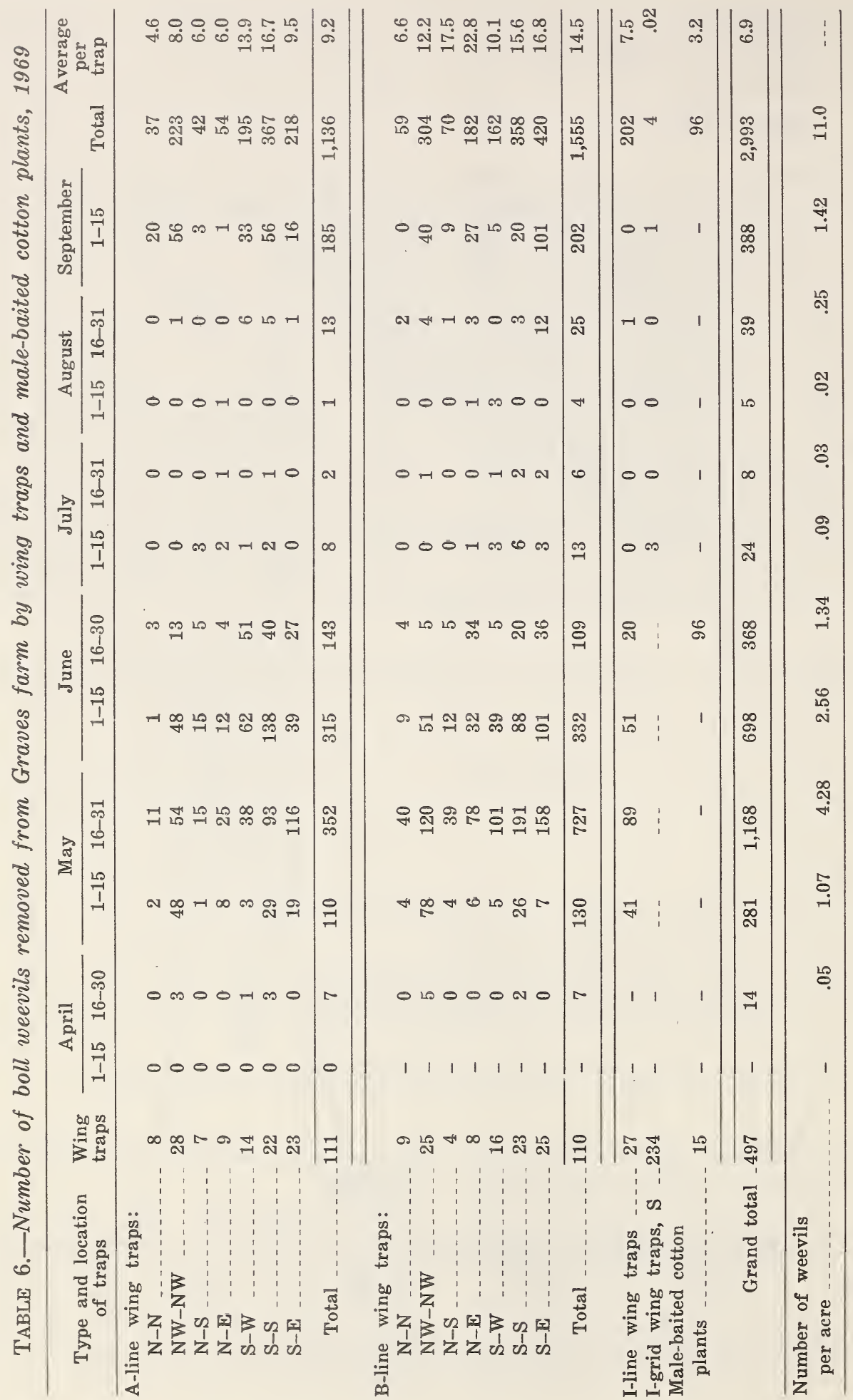


TABLE 7.-Sex ratio of boll weevils captured on pheromone wing traps positioned around Graves farm and survival of caged males in these traps, 1969

\begin{tabular}{|c|c|c|}
\hline Date & $\begin{array}{c}\text { Female boll } \\
\text { weevils captured } \\
\text { on trap }{ }^{1}\end{array}$ & $\begin{array}{l}\text { Survival of } \\
\text { caged male } \\
\text { boll weevils }\end{array}$ \\
\hline & Percent & Percent \\
\hline Apr. $1-15$ & . & 35 \\
\hline $16-30$ & $53(50)$ & 49 \\
\hline May $1-15$ & $67(50)$ & 60 \\
\hline $16-31$ & $47(50)$ & 64 \\
\hline June $1-15$ & $53(50)$ & 60 \\
\hline $16-30$ & $61(50)$ & 35 \\
\hline July $1-15$ & 85 (13) & 10 \\
\hline $16-31$ & $71(7)$ & 27 \\
\hline Aug. $1-15$ & $67(6)$ & 9 \\
\hline
\end{tabular}

${ }^{1}$ Numbers in parentheses are total number of boll weevils examined.

and during the first 2 weeks in August only 9 percent of the caged males survived the 3 to 4 days in the traps.

\section{Soil Applications of Aldicarb}

Methods.-The cotton on the entire Graves farm was treated with soil applications of aldicarb in further attempts to suppress the boll weevil. It might have been possible to eradicate the boll weevil with an integrated control program that included an effective fall spray program, pheromone wing traps, and one application of aldicarb (in-furrow or side-dress). However, both an in-furrow application at planting and a side-dressing to presquaring cotton were used to increase the chances for success of the eradication experiment.

The 273 acres of cotton on the Graves farm (with every third row not planted) were treated with 1 pound of actual aldicarb per acre at the time of planting on June 3-9, 1969. The insecticide granules were applied with the Lankart 57 variety cottonseed in prepared seedbeds using granular applicators attached to unit planters.

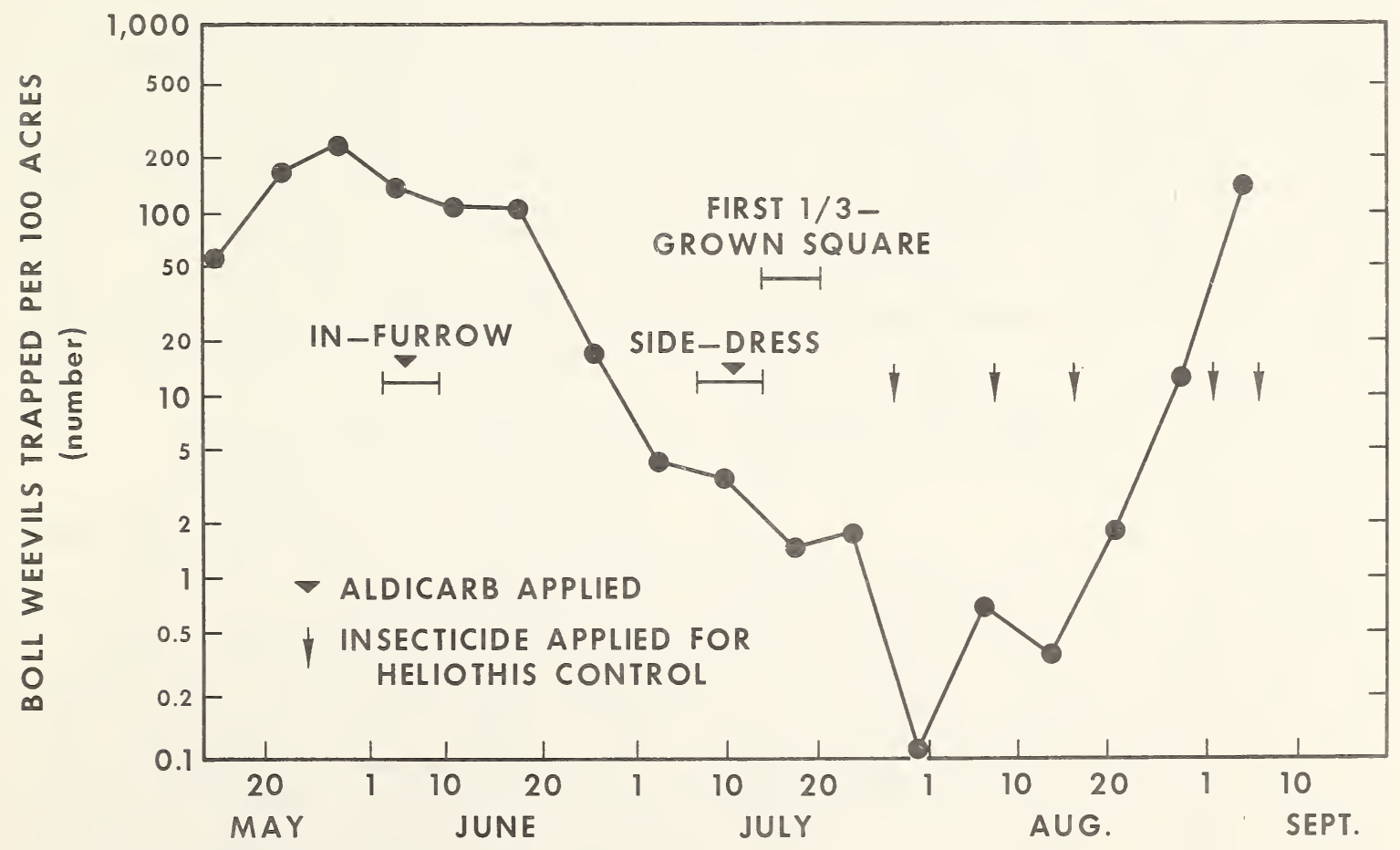

FIGURE 6.-Number of boll weevils removed from Graves farm by traps, timing of soil applications of aldicarb, and timing of foliar insecticide applications for Heliothis control, 1969. 
The cotton was side-dressed with 3 pounds of actual aldicarb per acre on July 9-15. The aldicarb was applied to both sides of each row of cotton, 6-7 inches deep and 9-10 inches to the sides of the plants, with two-row side-dress applicators.

Since the results of the aldicarb treatments cannot be readily separated from the effects of the pheromone traps, they will be reflected in discussing the sampling of insect populations.

\section{Sampling of Insect Populations}

Methods and Results.-The cotton on the Graves farm was sampled extensively by both manual and mechanical methods in an attempt to collect as much data as possible on the insect populations there. Manual random sampling for boll weevils on the Graves farm was initiated $21 / 2$ weeks after planting. From 0.15 to 0.61 acre of cotton was sampled weekly until September 1, 1969 (table 8). After September 1 from 0.02 to 0.22 acre of cotton was sampled at 5- to 15-day intervals.

At each inspection the number of boll weevil-damaged squares, Heliothis larvae, fruiting forms damaged by Heliothis larvae, and total fruiting forms were recorded. Normally only the fruiting forms one-third grown or larger were examined during inspections; consequently, only the Heliothis larvae that occurred in these forms were sampled. However, when economic infestations of Heliothis were suspected, the terminals and newly formed squares on from 200 to 400 row feet of cotton were inspected for Heliothis eggs and newly hatched larvae.

In addition to the regular random manual sampling, small areas of cotton that appeared particularly attractive to boll weevils were selectively sampled by plant examination and by collection and inspection of fallen squares.

From July 10 to September 8 from 1.5 to 10.7 acres of cotton were mechanically sampled weekly for adult boll weevils and boll weevildamaged squares with the insect-collecting machine previously described.

Although the cotton on the Graves farm was extensively sampled by manual and mechanical methods (table 8 ), not a single live boll weevil or boll weevil egg was found until September 2, about 1 week after the wing trap catches indicated extensive boll weevil movement had begun (figs. 4 and 6, tables 5 and 6 ). However, one dead boll weevil was found in a treated field on July 1 and six squares were found on August 4 and 13 that appeared to have been punctured by a boll weevil. All punctured squares were within a 0.04-acre area of cotton that was at the outer edge of a field and was the site where squares were first detected on the Graves farm during 1969. Microscopic examination confirmed oviposition punctures in two of these squares, but none of the squares contained any evidence of eggs or developing larvae. These punctures were apparently made by a single infertile female, which prepared the squares for oviposition but did not deposit viable eggs in them.

A damaging infestation of the beet armyworm (Spodoptera exigua (Hübner)), which required chemical control, was detected on the Graves farm on July 28, 1969. Four foliar applications of insecticide were required from August 8 to September 7 to control Heliothis (table 9). Methyl parathion (1.5 or 2 pounds of toxicant per acre) or toxaphene-DDTmethyl parathion (2-1.5-0.75 pounds of toxicant per acre) was used to control these pests. These applications would undoubtedly affect a developing boll weevil population. However, since the applications in July and August were made at 8- to 15-day intervals, they probably would not have prevented the boll weevil population from increasing.

The absence of a detectable boll weevil population on the Graves farm until after longrange migration of boll weevils began suggested that eradication of this pest was achieved. In compiling additional evidence on the possibility that this pest was eradicated from the Graves farm, mathematical computations were devised to estimate the maximum number of overwintered boll weevils that could have survived the various suppression measures and not have been detected. The formulas for these computations were as follows: 
Maximum number of undetected

(A) boll weevils per 100 acres

$=\frac{100}{\begin{array}{c}\text { Number of } \\ \text { acres } \\ \text { sampled }\end{array} \times \quad \begin{array}{c}\text { Rate of } \\ \text { increase }\end{array} \times \begin{array}{c}\text { Efficiency } \\ \text { of sampling } \\ \text { method }\end{array}}$

Maximum number of undetected

(B) boll weevils per 100 acres

$=\frac{100}{\begin{array}{c}\text { Number of } \\ \text { acres } \\ \text { sampled }\end{array} \times \quad \begin{array}{c}\text { Rate of } \\ \text { increase }\end{array} \times \begin{array}{c}\text { Number of } \\ \text { punctured } \\ \text { squares } \\ \text { per adult }\end{array} \times \begin{array}{c}\text { Efficiency } \\ \text { of sampling } \\ \text { method }\end{array}}$

TABLE 8.-Manual and mechanical sampling of cotton plants for boll weevils on Graves farm, 1969

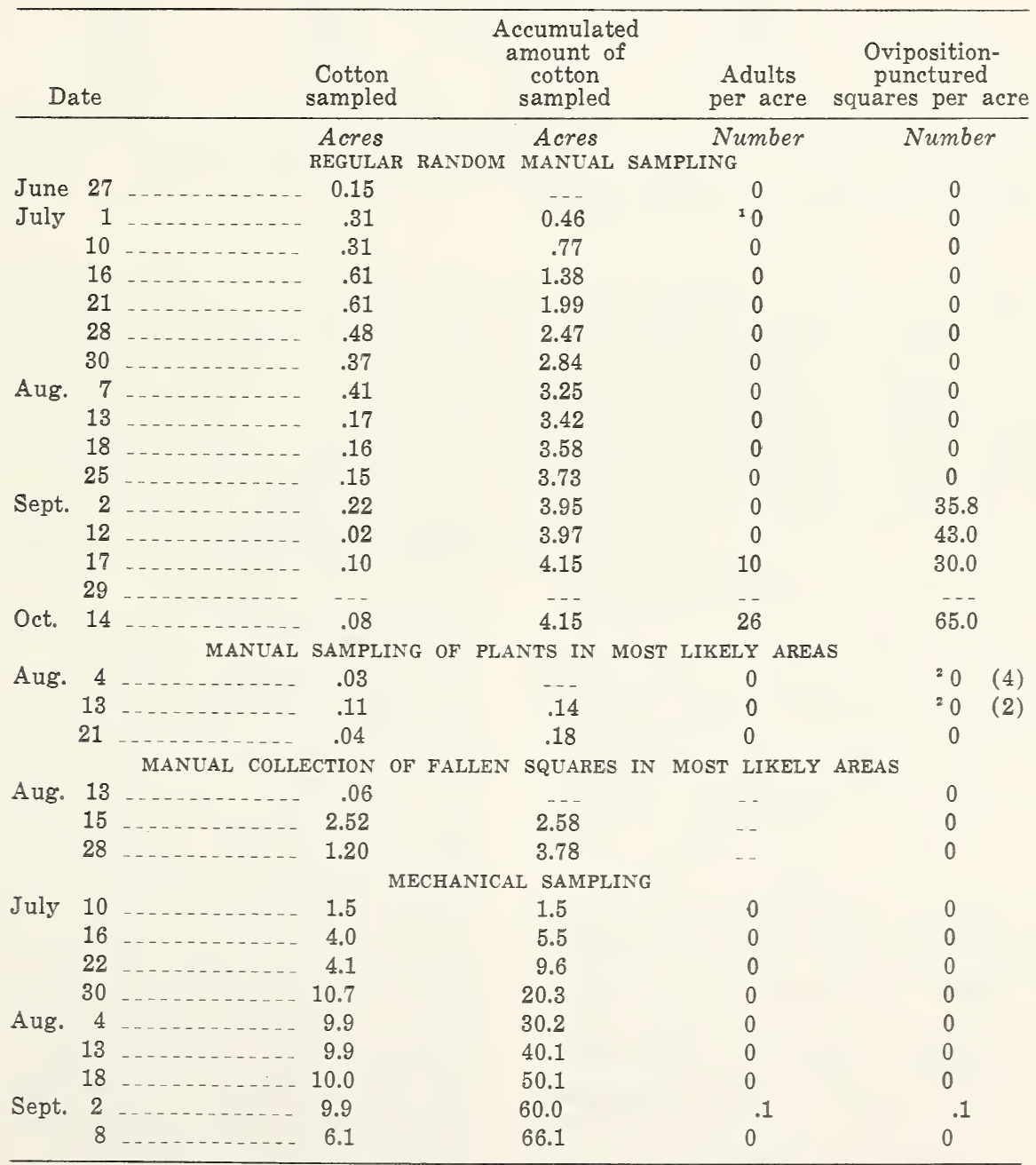

${ }^{1}$ One dead boll weevil found.

${ }^{2}$ Numbers in parentheses are numbers of squares containing probable oviposition punctures. However, these squares apparently did not contain eggs. 
TABLE 9.-Heliothis larvae and squares and bolls damaged by Heliothis larvae per acre on Graves farm, 1969

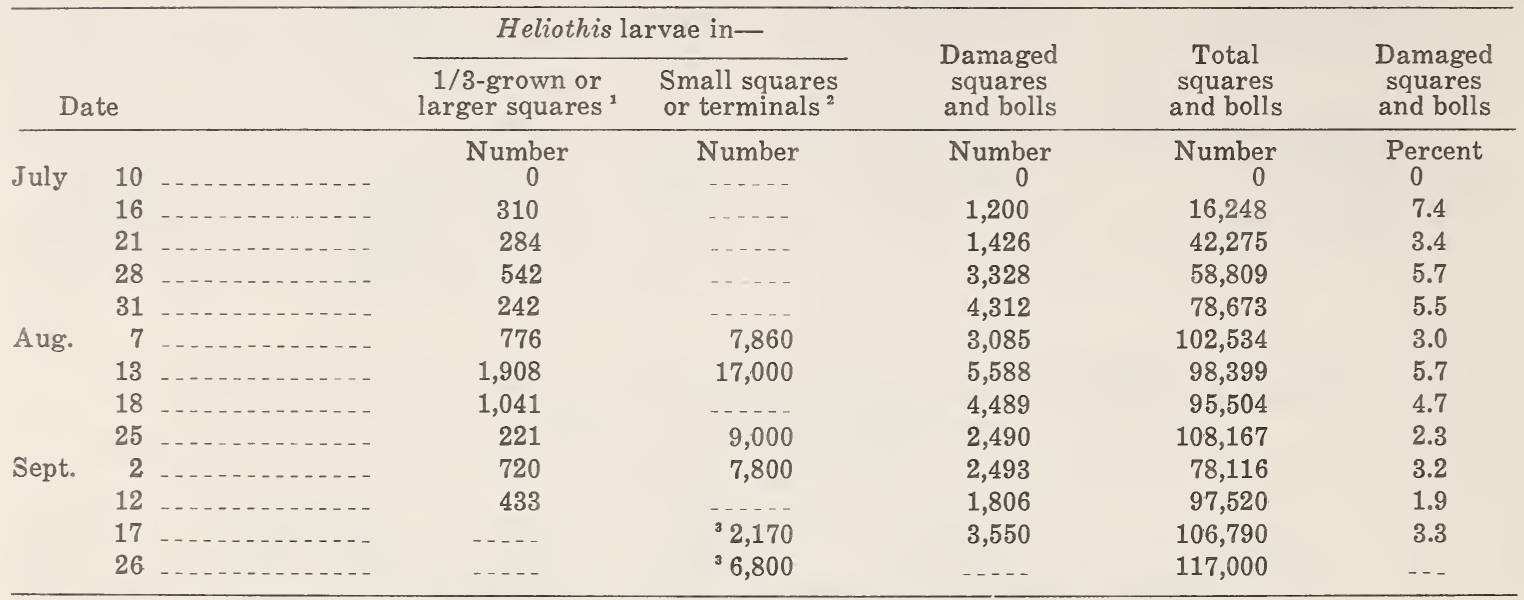

${ }^{1}$ Larvae found during routine sampling for boll weevils, usually third instar or larger.

${ }^{2}$ Larvae found during periodic sampling made especially for Heliothis, usually first or second instars.

${ }^{3}$ Larvae found following complete inspection of plants.

Both formulas will give an estimate of the maximum number of overwintered boll weevils per 100 acres of cotton that could have survived the suppression measures and gone undetected. The first method of computation (A) is based on sampling of adult boll weevils; the second (B) is based on sampling of punctured squares.

The numbers of acres of cotton sampled by the various methods at a given date are presented in table 8. Additional data needed for these computations were obtained from several sources. Data obtained by the manual sampling of an uncontrolled boll weevil population on a cotton farm (Sherrod farm), located about 20 air miles from the Graves farm, were used to estimate the rate of increase of the surviving boll weevil population on the Graves farm. The numbers of adult boll weevils and boll weevil-punctured squares per acre on the Sherrod farm during the summer of 1969 are presented in figure 7 . The data reported from this farm are slightly adjusted to compensate for a 5- to 7-day difference in planting dates between the two farms. To estimate the rates of increase of a boll weevil population on the Graves farm, the observed rates on the Sherrod farm were reduced by 50 percent in an attempt to compensate for the effects of the aerial applications of methyl parathion used for Heliothis and beet armyworm control on the Graves farm.

Manual sampling of fruiting cotton was estimated to be 50-percent effective for the detection of adult boll weevils ${ }^{4}$ and 75 -percent effective for the detection of punctured squares. For the computations, the efficiency of the insect-collecting machine was corrected to adjust for the efficiency of manual sampling.

The computations designed to estimate the maximum number of boll weevils that might have been present on the Graves farm and gone undetected resulted in a wide range of estimates depending on the assumptions made (table 10). However, because of the several methods of sampling used, the different stages sampled, and some sampling biased toward favorable boll weevil habitats, some of the lower estimates should be realistic values. Based on mechanical sampling of squares and manual collection of fallen squares and assuming a stable population, the maximum boll weevil population could have been one boll weevil for each 22 to 32 acres (4.5 to 3.1 weevils per

\footnotetext{
${ }^{4}$ Merkl, M. E., Boll Weevil Research Laboratory, State College, Miss., personal communication.
} 

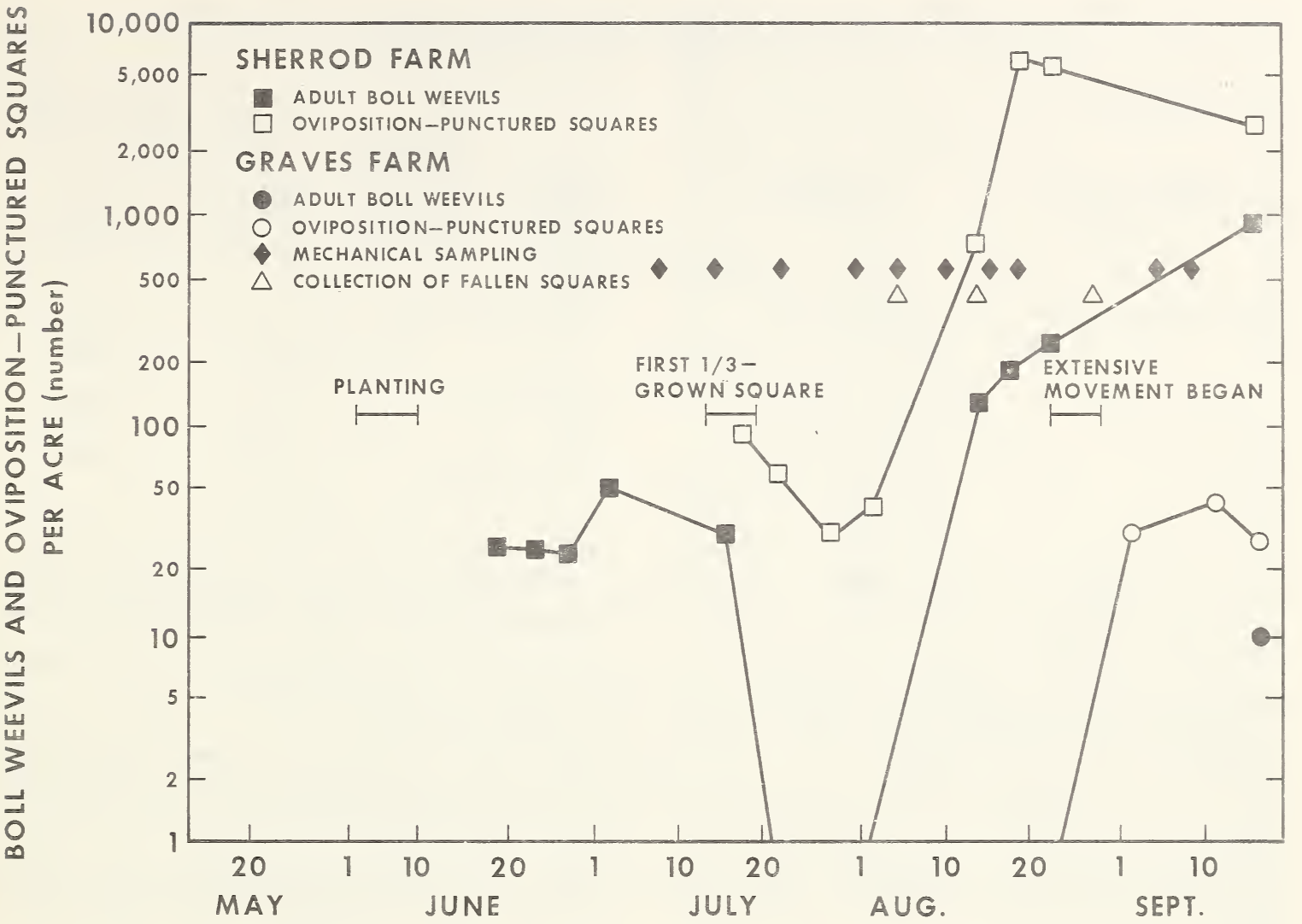

FIGURE 7.--Comparative population dynamics of boll weevil on Graves farm (eradication experiment) and on Sherrod farm (uncontrolled population), 1969.

100 acres), or if a moderate rate of increase is assumed, then the maximum population could have been one boll weevil per 37 to 100 acres ( 2.7 to 1 weevil per 100 acres).

Eradication of the boll weevil for the short period between depletion of overwintered boll weevils and the beginning of fall movement cannot be proved conclusively with the available data. However, the suppression techniques employed apparently were sufficiently effective to achieve maximum suppression of the boll weevil on the Graves farm. The absence of boll weevil egg-punctured squares until after the wing trap catches indicated extensive weevil movement and the presence of an infertile female are good evidence that the boll weevil population on this farm was reduced to such a level that reproduction was prevented. Very likely only the long-range movement of boll weevils from other cotton-growing areas prevented the permanent eradication of this pest from the Graves farm.

\section{Relative Value of Suppression Techniques on the Graves Farm and Feasibility of Eradication Plan for Belt-Wide Usage}

The data obtained on the Graves farm strongly indicate that boll weevil eradication was achieved. In view of these promising results, some consideration should be given to the relative contributions of each of the suppression measures to the eradication effort and 
TABLE 10.-Theoretical maximum populations of overwintered boll weevils remaining in cotton on Graves farm, 1969

\begin{tabular}{|c|c|c|c|c|c|c|}
\hline & \multirow[b]{2}{*}{$\begin{array}{l}\text { Estimated rate } \\
\text { of increase }\end{array}$} & \multirow[b]{2}{*}{$\begin{array}{l}\text { Sampling } \\
\text { period }\end{array}$} & \multirow[b]{2}{*}{$\begin{array}{l}\text { Cotton } \\
\text { sampled }\end{array}$} & \multirow{2}{*}{$\begin{array}{c}\text { Estimated } \\
\text { punctured } \\
\text { squares } \\
\text { per adult }\end{array}$} & \multicolumn{2}{|c|}{$\begin{array}{l}\text { Maximum boll weevils per } \\
100 \text { acres based on- }\end{array}$} \\
\hline & & & & & $\begin{array}{l}\text { Punctured } \\
\text { squares }\end{array}$ & Adults \\
\hline & & MANUAL & $\begin{array}{c}\text { Acres } \\
\text { SPECTION }^{2}\end{array}$ & Number & Number & Number \\
\hline \multirow{2}{*}{\multicolumn{2}{|c|}{ 1X (population stable) }} & June 27-Aug. $25 \ldots$ & 3.73 & & & 53.5 \\
\hline & & July $21-A$ ug. 18 & 2.35 & ${ }^{3} 10$ & 5.6 & 84.7 \\
\hline \multirow[t]{2}{*}{$2 \mathrm{X}$} & & Aug. $18-25$ & .31 & ${ }^{4} 30$ & 7.1 & 31.0 \\
\hline & & MECHANIC & SAMPLING $^{5}$ & & & \\
\hline \multirow{3}{*}{$\begin{array}{l}1 \mathrm{X} \\
2 \mathrm{X}\end{array}$} & & July 10-Aug. 18 & 50.6 & ..- & $\ldots$ & 10.3 \\
\hline & & July 22-Aug. 18 & 42.6 & ${ }^{3} 10$ & 4.5 & 12.2 \\
\hline & & Aug. 18 & 10.0 & ${ }^{4} 36$ & 2.7 & 26.3 \\
\hline $2 \mathrm{X}$ & & MANUAL COLLECTI & OF FALLEN & JARES & & \\
\hline $1 \mathrm{X}$ & - & Aug. 28 & 1.2 & ${ }^{4} 36$ & 3.1 & $\ldots$ \\
\hline $3 \mathrm{X}$ & - & Aug. 28 & 1.2 & ${ }^{4} 36$ & 1.0 & $\ldots$ \\
\hline
\end{tabular}

${ }^{1}$ Rates of increase ( $2 \mathrm{X}$ and $3 \mathrm{X}$ ) based on uncontrolled population on Sherrod farm after assuming that insecticide applications made on Graves farm for controlling beet armyworm and bollworms resulted in 50-percent reduction of boll weevils.

${ }^{2}$ Manual sampling of fruiting cotton estimated to be 50- and 75-percent efficient in detecting adult boll weevils and boll weevil-punctured squares, respectively. All reported values are corrected accordingly.

${ }^{3}$ General estimate based on records taken in 1968 and 1969 in same general area.

${ }^{4}$ Based on adult-punctured square ratios found on Sherrod farm. Thirty punctured squares per adult based on average of records taken on adjusted dates of Aug. 18-25; 36 punctured squares per adult based on average of records taken on adjusted date of Aug. 18; squares punctured by this date should have fallen to the ground by Aug. 28.

${ }^{5}$ Machine sampling of fruiting cotton was corrected for efficiency of manual sampling, i.e., $38.67 \times 0.50=19.3-$ percent efficient for detecting adult boll weevils and $6.8 \times 0.75=5.1$-percent efficient for detecting punctured squares.

to the feasibility of applying the same techniques in a belt-wide eradication program.

Although a good assessment of the combined effects of the suppression measures was obtained, it was not possible to directly measure the contribution of each measure. Therefore, estimates of the relative value of fall applications of insecticides, spring application of the systemic insecticide, and the male-baited pheromone wing traps must be based primarily on previous studies.

Available data on the use of insecticide applications in the fall and of aldicarb in the spring indicate that when either of these methods is properly used, a 90- to 99-percent reduction in boll weevils can be expected. Although the monitoring of boll weevil populations on the Graves farm showed that maximum suppression from insecticides applied in the fall probably was not achieved, the use of both in-furrow and side-dress applications of aldicarb could be expected to provide suppression considerably in excess of the 95 percent commonly obtained in northwest Texas when only one of the applications is made.

The value of the wing traps is the most difficult to assess since less information as to their value for population suppression is available. Several factors lead us to conclude that malebaited pheromone wing traps destroyed a smaller percentage of the boll weevil population than the other two suppression measures. For instance, when free-living males on plants were compared for attractiveness with living males in traps, the data indicated that the wing traps were not competitive with males on fruiting cotton. Also, substantial mortality of insects in the traps would further indicate that limited 
pheromone production occurred. Although the traps were not fully competitive, they did remove a substantial number of boll weevils from the population and thus contributed significantly to the eradication effort. In addition, the pheromone produced by the caged weevils may have confused any possible surviving weevils and made it difficult for them to find a mate. In fact, the evidence of an unmated female in the cotton on the Graves farm appears to substantiate this possibility.

Any attempt to evaluate the feasibility and value of the eradication plan for the Graves farm for use in other areas of the United States should include the consideration that northwest Texas is probably one of the most ideal areas in the boll weevil-infested Cotton Belt to demonstrate boll weevil eradication. The cold winters and limited hibernation quarters in this area limit the number of weevils that successfully overwinter, and the hot, dry summers limit the rate of increase of the surviving boll weevils, especially in nonirrigated cotton. ${ }^{5}$ In addition, the early emergence of boll weevils relative to planting in this area substantially increases the effectiveness of soil applications of aldicarb (Ridgway et al. 1971).

Although the eradication plan presented here apparently succeeded in demonstrating the technical feasibility of boll weevil eradication, similar results might not be obtained in other areas. Nevertheless we believe that the suppression techniques used on the Graves farm do have a place in a belt-wide eradication program. The extent of using a suppression method in such a program will depend on its possible advantages and limitations when used over large areas.

Available data on reproduction-diapause boll weevil control indicate this suppression method is suitable for use over large areas. The fall application of insecticides over a large area near the High Plains of Texas for several years has provided effective boll weevil control without seriously upsetting the ecosystem.

\footnotetext{
${ }^{5}$ Sterling, W. L. POPUlation DYNAMics AND SEASONAL HISTORY OF THE BOLL WEEVIL ANTHONOMUS GRANDIS BOHEMAN IN THE SEMI-ARID HIGH AND ROLLING PLAINS OF TEXAS. 1969. [Unpublished Ph.D. dissertation. Copy on file Texas A\&M Univ., College Station.]
}

However, further testing on very large acreages in other areas of the Cotton Belt with detailed monitoring of all effects is probably desirable to insure that the fall applications can be satisfactorily used elsewhere.

Soil applications (in-furrow or side-dress) of aldicarb probably provide one of the most effective proved methods for suppressing boll weevils. However, a careful consideration of both the limitations and advantages of the suppression technique is essential before widespread use is suggested.

One of the most important limitations of using aldicarb is its effect on beneficial insects and the resulting increase of bollworms (Ridgway et al. 1967; Coppedge et al. 1969). Aldicarb is highly toxic to warm-blooded animals (Anonymous 1970). Extreme care must be taken to avoid spilling granules and to immediately clean up spills that do occur, since birds and wildlife may be killed if allowed to feed on exposed granules. Effective side-dress treatments against the boll weevil require precise timing, and inclement weather can delay these applications for several days.

In view of the potential value of aldicarb, we believe that additional research should be conducted in which larger acreages in other cotton-growing areas are treated. Such research should provide information needed to make judgments concerning the extent to which aldicarb should be applied in an eradication program. Also, we believe that the selective use of aldicarb, in which 10 to 20 percent of the heaviest infested cotton acreage would be treated, probably offers a method of taking advantage of this highly effective suppression tool and of limiting the undesirable side effects that may be associated with the treatment.

As a part of this approach to utilizing aldicarb, we would suggest the use of biological agents to regulate damaging populations of bollworms or tobacco budworms that might be associated with applying aldicarb. Specifically the use of preparations of Bacillus thuringiensis (Berliner) (R. E. Kinzer and R. L. Ridgway unpublished data) and the release of predators (Ridgway 1972) or parasites (Cate et al. 1972) have potential in controlling boll- 
worms on cotton that has been treated with aldicarb.

Also, the use of aldicarb-treated trap plots in connection with the boll weevil pheromone may provide a valuable selective use of aldicarb since this combination provided the most effective trap in experiments comparing several kinds of trapping systems.

Calculations based on the basic principles associated with the utilization of pheromones in population regulation clearly emphasize the potential use of pheromones (Knipling and McGuire 1966). In addition, the development of a synthetic pheromone (Tumlinson et al. 1969) provides a potentially economical substitute for the caged weevils. Further definition of the value of pheromones in the suppression or confusion of boll weevils should lead to the development of methods for using the pheromone in an eradication program.

Although sterile males were not available for our experiments, this method is probably still the most effective in eliminating the last few insects in a population. The discovery of what appears to be a more satisfactory method of sterilizing boll weevils (Klassen et al. 1968; Klassen and Earle 1970) may provide the needed information to perfect the sterile male techniques for widespread use.

The availability of the various methods of suppressing boll weevils, including fall and spring applications of insecticides, pheromones, and sterile males, and the success of the experiment on the Graves farm provide substantial evidence that eradication of the boll weevil from the major cotton-producing areas in the United States is technically feasible. Additional large-scale experimentation will be required to determine how the various suppression methods can be best used and to determine the practical feasibility of applying the required suppression methods to large areas.

\section{SUMMARY}

The initial step in demonstrating the feasibility of boll weevil eradication was to critically review the most promising current suppression techniques. Next, several supporting experiments were designed to provide additional information on certain suppression methods. Finally, an experiment was planned specifically to demonstrate the technical feasibility of boll weevil eradication.

The supporting experiments included studies of (1) in-furrow applications of aldicarb for boll weevil control, (2) boll weevil trapping systems, and (3) mechanical sampling of boll weevils on fruiting cotton plants. For the specific eradication experiment, the suppression techniques selected were (1) reproductiondiapause control, (2) pheromone wing traps, and (3) in-furrow and side-dress applications of aldicarb.

In the supporting experiments, the infurrow applications of aldicarb to cotton in the Rolling Plains of Texas in 1969 provided excellent control of overwintered boll weevils. Although slightly more Heliothis larvae and more squares and bolls damaged by this insect were found in treated than untreated cotton, damaging infestations of Heliothis requiring chemical control did not develop in any of the treated cotton.

A comparison of various combinations of cotton plants, cotton plants treated with aldicarb, and male-baited wing traps indicated that cotton plants treated with aldicarb plus malebaited wing traps attracted or destroyed the most boll weevils. A comparison of male-baited cotton plants with male-baited wing traps indicated that the plants were four to eight times more efficient in attracting boll weevils than the traps.

In sampling adult boll weevils and squares damaged by them on fruiting cotton, a sampling machine was 38.5-percent efficient in collecting adults and 6.8-percent efficient in collecting punctured squares when compared with manual sampling.

The specific experiment designed to demonstrate the technical feasibility of boll weevil eradication was conducted on the semi-isolated Graves farm in King County, Tex. The cotton on this farm was isolated from other cotton by 13 to 15 air miles. A reproduction-diapause 
control program was implemented on this farm in the fall of 1968.

The next phase of this eradication experiment included the use of pheromone wing traps to monitor boll weevil movement. Trap catches indicated that the boll weevils moved extensively during May and early June. Movement decreased during the last part of June but increased greatly about September 1. Minimal catches during the last part of July and most of August indicated that the Graves farm was reasonably isolated during this period.

Additional wing traps were placed immediately around the Graves farm to suppress the boll weevil population. They removed an equivalent of 9.5 weevils per acre from this farm between April 1 and August 15.

Further attempts to suppress boll weevils on the Graves farm included in-furrow applications of aldicarb at planting (1 pound per acre) and side-dressing applications at squaring ( 3 pounds per acre) to all 273 acres of cotton planted on the farm. Five foliar insecticide applications were made on this farm between July 28 and September 6, 1969, to control Heliothis and other pests.

The cotton on the Graves farm was sampled extensively for boll weevils by both manual and mechanical methods. Manual random sampling was initiated approximately 21/2 weeks after planting and was continued at weekly intervals. In addition, small areas of cotton that seemed particularly attractive to boll weevils were selectively sampled by plant examination and by collection of fallen squares. Also, 1.5 to 10.7 acres of cotton were sampled weekly with an insect-collecting machine.

Live boll weevils were not detected in cotton until after long-range movement of this insect began. However, six squares that appeared to have boll weevil oviposition punctures were found within a 0.04-acre area during the first 2 weeks in August. Microscopic examination confirmed oviposition punctures in at least two of the squares, but none of them contained any evidence of eggs or developing larvae.

The extensive sampling that failed to detect any living boll weevils in cotton on the Graves farm until after September 1 and the presence of an infertile female indicated that boll weevil reproduction was prevented until the insects began to move onto the farm from adjacent cotton. Based on calculations of the maximum population of overwintered boll weevils that remained on the farm, the overwintered population can be estimated to have been as low as one boll weevil per 100 acres.

\section{LITERATURE CITED}

\section{ANONYMOUS.}

1970. TECHNICAL INFORMATION ON TEMIK (B) $10 \mathrm{G}$ ALDICARB PESTICIDE. $67 \mathrm{pp}$. Union Carbide Corp., New York.

Adkisson, P. L., Davis, J. W., Owen, W. L., and RumMEL, D. R.

1965. EVALUATION OF THE 1964 DIAPAUSE BOLL WEEVIL CONTROL PROGRAM ON THE HIGH Plains of texas. Tex. Agr. Expt. Sta. Dept. Ent. Tech. Rpt. 2, 29 pp.

and Sterling, W. L.

1965. TWO-PHASED CONTROL PROGRAM FOR REDUCING DIAPAUSE BOLL WEEVIL POPULATIONS IN THE HIGH PLAINS OF TEXAS IN 1965. Tex. Agr. Expt. Sta. Dept. Ent. Tech. Rpt. 2, 6 pp.

Bariola, L. A., Ridgway, R. L., and Coppedge, J. R. 1971. LARGE SCALE FIELD TESTS WITH SOIL APPLICATIONS OF ALDICARB FOR SUPPRESSION OF Boll WEEVIL POPUlations. Jour. Econ. Ent. 64: 1280-1284.
Brazzel, J. R.

1961. DESTRUCTION OF DIAPAUSE BOLL WEEVILS AS A MEANS OF BOLL WEEVIL CONTROL. Tex. Agr. Expt. Sta. Pub. 511, 6 pp.

Davich, T. B., and Harris, L. D.

1961. A NEW APPROACH TO BOLL WEEVIL CONTROL. Jour. Econ. Ent. 54: 723-730.

and Newsom, L. D.

1959. DIAPAUSE IN ANTHONOMUS GRANDIS (BOHEMAN). Jour. Econ. Ent. 50: 603-611.

Cate, J. R., Jr., Ridgway, R. L., and Lingren, P. D. 1972. EFFECTS OF COTTON PLANTS TREATED WITH SYSTEMIC INSECTICIDES ON AN ICHNEUMONID PARASITE, CAMPOLETIS PERDISTINCTUS. Jour. Econ. Ent. 65: 484-488.

Coppedge, J. R., Lindquist, D. A., Ridgway, R. L., and others.

1969. SIDE-DRESS APPLICATIONS OF UNION CARBIDE UC-21149 FOR CONTROL OF OVERWINTERED BoLl WeEvils. Jour. Econ. Ent. 62: 558565 . 
Cowan, C. B., JR., RIDGWaY, R. L., DAvis, J. W., and others.

1966. SYSTEMIC INSECTICIDES FOR CONTROL OF COTTON INSECTS. Jour. Econ. Ent. 59: 958961.

Cross, W. H., Hardee, D. D., Nichols, F., and others.

1969. ATTRACTION OF FEMALE BOLL WEEVILS TO TRAPS BAITED WITH MALES OR EXTRACTS OF MALES. Jour. Econ. Ent. 62: 154-161.

and Mitchell, H. C.

1966. MATING BEHAVIOR OF THE FEMALE BOLL WEEvIL. Jour. Econ. Ent. 59: 1503-1507.

Daum, R. G., Mclaughlin, R. E., and Hardee, D. D.

1967. DEVELOPMENT OF THE BAIT PRINCIPLE FOR BOLL WEEVIL CONTROL: COTTONSEED OIL A SOURCE OF ATTRACTANTS AND FEEDING STIMULANTS FOR THE BOLL WEEVIL. Jour. Econ. Ent. 60: 321-325.

Davich, T. B., Keller, J. C., Mitchell, E. B., and others.

1965. PRELIMINARY FIELD EXPERIMENT WITH STERILE MALES FOR ERADICATION OF THE BOLL WEEVIL. Jour. Econ. Ent. 58: 127131.

and LiNDQuist, D. A.

1962. EXPLORATORY STUDIES ON GAMMA RADIATION FOR THE STERILIZATION OF THE BOLL WEEVIL. Jour. Econ. Ent. 55: 164-167.

Merkl, M. E., Mitchell, E. B., and others.

1967. FIELD EXPERIMENTS WITH STERILE MALES FOR ERADICATION OF THE BOLL WEEVIL. Jour. Econ. Ent. 60: 1533-1538.

Ewing, K. P., and Parencia, C. R.

1949. EARLY SEASON APPLICATION OF INSECTICIDES FOR COTTON INSECT CONTROL. U.S. Bur. Ent. and Plant Quar. E-792, 9 pp.

Fye, R. E., Cole, C. L., Tingle, F. C., and others.

1968. A REPRODUCTIVE-DIAPAUSE CONTROL PROGRAM FOR THE BOLL WEEVIL IN THE PRESIDO, TEXASOJINAGA, CHIHUAHUA AREA, 1965-1967. Jour. Econ. Ent. 61: 1660-1666.

Gast, R. T., and Davich, T. B.

1966. BOLL WEEvILS. In Smith, C. N., Insect Colonization and Mass Production, pp. 405-418. Academic Press, New York.

Hardee, D. D., Cross, W. H., Huddleston, P. M., and DAVICH, T. B.

1970. SURVEY AND CONTROL OF THE BOLL WEEVIL IN WEST TEXAS WITH TRAPS BAITED WITH MALES. Jour. Econ. Ent. 63: 1041-1048.

Cross, W. H., and Mitchell, E. B.

1969. MALE BOLL WEEVILS ARE MORE ATTRACTIVE THAN COTTON PLANTS TO BOLL WEEVILS. Jour. Econ. Ent. 62: 165-169.

Mitchell, E. B., and Huddleston, P. M.

1966a. CHEMORECEPTION OF ATTRACTANTS FROM THE COTTON PLANT BY BOLL WEEVILS, ANTHONOMUS GRANDIS (COLEOPTERA: CURCULIONIDAE). Ent. Soc. Amer. Ann. 59: 867-868.
Mitchell, E. B., and Huddleston, P. M.

1966b. EFFECT OF AGE, NUTRITION, SEX, AND TIME OF DAY ON RESPONSE OF BOLL WEEVILS TO AN ATTRACTANT FROM COTTON. Ent. Soc. Amer. Ann. 59: 1024-1025.

Mrtchell, E. B., Huddleston, P. M., and DAVICH, T. B.

1966c. A LABORATORY TECHNIQUE FOR BIOASSAY OF PLANT ATTRACTANTS FOR THE BOLL WEEVIL. Jour. Econ. Ent. 59: 240-241.

Hopkins, A. R., and TAFT, H. M.

1965. CONTROL OF CERTAIN COTTON PESTS WITH A NEW SYSTEMIC INSECTICIDE, UC-21149. Jour. Econ. Ent. 58: 746-749.

Keller, J. C., Davich, T. B., MaXwell, F. G., and others.

1965. EXTRACTION OF A BOLL WEEVIL ATTRACTANT FROM THE ATMOSPHERE SURROUNDING GROWING COTTON. Jour. Econ. Ent. 58: 588589.

T. B.

MAXwell, F. G., Jenkins, J. N., and DAVICH,

1963. A BOLL WEEVIL ATTRACTANT FROM COTTON. Jour. Econ. Ent. 56: 110-111.

T. B.

Mitchell, E. B., McKibben, G. H., and Davich,

1964. A SEX ATTRACTANT FOR FEMALE BOLL WEEVILS FROM MALES. Jour. Econ. Ent. 57: 609-610.

Kirk, I. W., and BotTrell, D. G.

1969. A MECHANICAL SAMPLER FOR ESTIMATING BOLl WeEvil POPUlations. Jour. Econ. Ent. 62: 1250-1251.

KLASSEN, W., and EARLE, N. W.

1970. PERMANENT STERILITY INDUCED IN BOLL WEEVILS WITH BUSULFAN WITHOUT REDUCING PKODUCTION OF PHEROMONE. Jour. Econ. Ent. 63: 1195-1198.

Norland, F., and Borkovec, A. B.

1968. POTENTIAL CHEMOSTERILANTS FOR BOLL WEEvils. Jour. Econ. Ent. 61: 401-407.

KNIPLING, E. F.

1964. THE POTENTIAL ROLE OF THE STERILITY METHOD FOR INSECT POPULATION CONTROL WITH SPECIAL REFERENCE TO COMBINING THIS METHOD WITH CONVENTIONAL METHoDs. U.S. Dept. Agr. ARS 33-98, 55 pp.

1968. TECHNICALLY FEASIBLE APPROACHES TO BOLL WEEVIL ERADICATION. Beltwide Cotton Prod.-Mech. Conf., Hot Springs, Ark., Sum. Proc. 1968 (Jan.), pp. 14-18.

and McGuire, J. U., JR.

1966. POPULATION MODELS TO TEST THEORETICAL EFFECTS OF SEX ATTRACTANTS USED FOR INSECT CONTROL. U.S. Dept. Agr. Inform. Bul. $308,20 \mathrm{pp}$. 
LINDQUIST, D. A., GoRTYCKI, L. J., MAYER, M. S., and others.

1964. LABORATORY STUDIES ON STBRHIZATTON OF THE BOLL WEEVIL WITH APHOLATE. JoUT. Econ. Ent. 57: 745-750.

LLOYD, E. P., LASTER, M. L., and MERKL, M. E.

1964. A FIELD STUDY OF DLAPACSE, DLAPAUSE CONTROL AND POPLLATION DYNAMICS OF THE BOLL WEEVIL. Jour. Econ. Ent. 57: 433436.

Mally, F. W.

1901 THE MEXICAN COTTON BOLL WEEVIL. U.S. Dept. Agr. Farmers' Bul. 130, 30 pp.

NEFF, D. L., and VANDERZANT, E. S.

1963. METHODS OF EVALUATING THE CHEMOTROPIC RESPONSE OF BOLL WEEVILS TO EXTRACTS OF THE COTTON PLANT AND VARIOUS OTHER SCBSTANCES. Jour. Econ. Ent. 56: 761-766.

RIDGWAY, R. L.

1972. SYSTEMIC INSECTICIDES SUPPLEMIENTED WITH INUNDATTVE RELLASES OF CBRYSOPA CARNEA STEPHENS, FOR COTTON INSECT CONTROL. Proc XIII, InternatI. Cong. Ent., Moscow, U.S.S.R. (1968). Vol. II, p. 175.
BARTOLA, L. A., and HARDER, D. D.

1971. SEASONAL MOVEMENT OF BOLL WEEVILS NEAR THE HIGH PLAINS OF TERAS. Jour. Econ. Ent. 62: 14-19.

and GorTYCKI, L. J.

1965. EVALTATION OF SOME EXPERTMENTAL PHOSPHORCS AND CARBAMATE COMPOUNDS AS SYSTEMIC INSECTICIDES. U.S. Dept. Agr. ARS 33-106, 6 pp.

D. A.

JONES, S. L., COPPEDGE, J. R., and LINDQUIST,

1968. SYSTEMIC ACTIVITY OF 2-METHYL-2 (METHY) THIO) PROPIONALDEHYDE O-(METHYLCARBAMOYL) OXIME (CC-21149) IN COTTON PLANTS WITH SPECTAL RBFERENCES TO THE BOLL WEEVIL. Jour. Econ. Ent. 61: 17051712.

J. W.

LINGreN, P. D., CowaN, C. B., JR, and Davis,

1967. POPULATIONS OF ARTHROPOD PRTDATORS AND HIHIOTHIS SPP. AFTER APPUCATION OF SYSTEMIC INSECTICIDES. Jour. Econ. Ent 60: 1012-1016.

Tumuivson, J. H., HardeE, D. D., GUIdDNER, R. C., and others.

1969. SEX PHEROMONES PRODUCED BY MALE BOLL WEEVILS: ISOLATION, IDENTIFICATION AND SYNTHESIS. Science 166: 1010-1012. 
This publication reports research involving pesticides. It does not contain recommendations for their use, nor does it imply that the uses discussed here have been registered. All uses of pesticides must be registered by appropriate State and/or Federal agencies before they can be recommended. CAUTION: Pesticides can be injurious to humans, domestic animals, desirable plants, and fish or other wildlife-if they are not handled or applied properly. Use all pesticides selectively and carefully. Follow recommended practices for the disposal of surplus pesticides and pesticide containers.

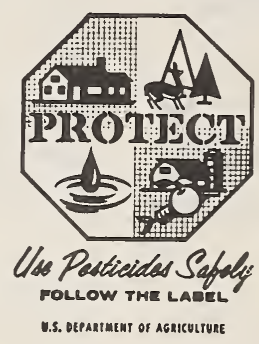

Trade names and names of commercial organizations are used in this publication solely for the purpose of providing specific information. Mention of a trade name or manufacturer does not constitute a guarantee or warranty of the product by the U.S. Department of Agriculture or an endorsement by the Department over other products not mentioned. 